\title{
Sensory mechanisms in dentine: A literature review of light microscopy (LM), transmission microscopy (TEM), scanning microscopy (SEM) \& electro physiological (EP) tooth sensitivity: Is the ciliary organelle on the odontoblast the elusive primary nociceptor?
}

\author{
Charles F Cox ${ }^{1 *}$, Keizo Suzuki ${ }^{2}$, Hiroyasu Yamaguchi ${ }^{3}$,John D Ruby ${ }^{4}$, Shiro Suzuki ${ }^{5}$, Naotake Akimoto ${ }^{6}$, Nobuko Maeda ${ }^{7}$ and Yasuko Momoi \\ ${ }^{1}$ Visiting Professor, Department of Operative Dentistry, School of Dental Medicine, Tsurumi University, 2-1-3, Tsurumi, Tsurumi-ku, Yokohama 230-8501, Japan \\ ${ }^{2}$ Visiting Research Fellow, Department of Public Health, Sapporo Medical University, School of Medicine, S1 W17, Chuo-ku, Sapporo, 060-8556, Japan \\ ${ }^{3}$ Professor, Department of Research in Dentistry \& Advanced Medical Technology Institute for Research \& Education of Preemptive Medicine, Tsurumi University, \\ 2-1-3, Tsurumi, Tsurumi-ku, Yokohama 230-8501, Japan \\ ${ }^{4}$ Adjunct Professor, Department of Pediatric Dentistry, School of Dentistry, 1919 7th Ave. S. The Univ. of Alabama at Birmingham, AL 35294, USA \\ ${ }^{5}$ Visiting Professor, Department of Clinical \& Community Science, 1919 7th Ave. S. The University of Alabama at Birmingham, AL 35294, USA \\ ${ }^{6}$ Part Time Lecturer, Department of Operative Dentistry, School of Dental Medicine, Tsurumi University, 2-1-3, Tsurumi, Tsurumi-ku, Yokohama 230-8501, Japan \\ ${ }^{7}$ Vice Chancellor, Department of Oral Microbiology, School of Dental Medicine, Tsurumi University 2-1-3, Tsurumi, Tsurumi-ku, Yokohama 230-8501, Japan \\ ${ }^{8}$ Chairperson, Department of Operative Dentistry, School of Dental Medicine, Tsurumi University, 2-1-3, Tsurumi, Tsurumi-ku, Yokohama 230-8501, Japan
}

\begin{abstract}
Ancient humans believed in myths—-that tooth pain was due to evil spirits [1]. Homer-the Greek author even wrote of tooth pain in his classical epics [2]. The European renaissance - circa 1350 to 1600-attributed tooth pain to worms that were allegedly found in tooth lesions [3]. Scientific methodology has described 3-theories of dentine sensitivity: (1) In 1770 Hunter suggested tooth sensitivity was due to pulpal nerves [4]. (2) In 1842 Neill $1^{\text {st }}$ proposed that tooth sensitivity was due to fluid movement in the dentine tubules [5]. (3) In $1856 \mathrm{~J}$ Tomes implicated odontoblast processes (OP's) in the dentine tubules as initiating tooth sensitivity [6]. In 1899 Gysi reported that dentine sensitivity was clinically activated by fluid-flow in the dentine tubules [7]. In 1968 Brännström proposed the hydrodynamic fluid-flow theory of dentine sensitivity [8]. Using LM \& TEM Mummary (1916), Tiegs (1938), Bernick (1948), Fearnhead (1961), Itoh (1976) \& others observed nerve fibers in the predentine \& dentine tubules. Using TEM Arwill (1967) described 8-sub-patterns of nerve fibers in the dentine tubules \& Frank (1968a, 1972, 1975). Corpron \& Avery (1973) observed nerve fibers extending $\approx 150 \mu \mathrm{m}$ from the predentine interface into the dentine tubules by TEM. Detailed LM, TEM \& SEM studies-by Gunji-reported 4-nerve patterns in the predentine-dentine region. In 1958 Avery \& Rapp reported acetylcholine receptors on odontoblasts. Some primate OP's have been shown to extend the length of the dentine tubule [9] \& some cross the basement membrane of the enamel-dentine-junction (EDJ) as enamel spindles. All eukaryotic cells display cilia, which are classified as specialized motile or sensory organelles that mediate gradients of sensory perception e.g. pressure, fluid-flow, which perceive environmental stimuli. TEM studies show cilia—extending from odontoblasts into the dentine tubule-suggesting they may be the initial mechano-nociceptor of dentine sensitivity [10].
\end{abstract}

\section{Historical review of dentine sensitivity}

It's likely that nearly every individual from antiquity to present day has experienced some degree of tooth pain-either during prophylaxis or with some aspect of restorative treatment or tooth extraction. The focus of our review is to discuss the morphological \& physiological aspects of odontoblasts, OP \& their cilia, nerves in predentine tubules \& dentine tubule fluid-each of which is a likely candidate to perceive external stimuli. We will consider if human dentine is supplied only by sensory nerve fibers \& explore if the OP ciliary organelles is the primary nociceptor apparatus to perceive stimuli. Specialized junctional complexes between odontoblasts \& OP's may spread an impulse thru an odontoblastic syncytium of millions of cells, which rapidly relays sensory impulses to the brain via sensory nerves as acute physiological pain.
Before scientific thought, there were numerous oral legends \& myths-amongst the less learned groups of antiquity-which circulated amongst humans that had encountered acute or chronic tooth pain. "Ancient myths basically amounted to the floating-talk of

Correspondence to: Charles F Cox, DMD, PhD, Department of Operative Dentistry, School of Dental Medicine, Tsurumi University, 2-1-3, Tsurumi, Tsurumi-ku, Yokohama 230-8501, Japan, Tel: (810)-275-8361; Fax: (810)-6364201; E-mail: cfcox@phoenixdental.com

Key words: dentine-tubules, nerves, odontoblast-processes, hydrodynamic-fluidflow, ciliary-nociceptors

Received: November 20, 2017; Accepted: December 06, 2017; Published: December 09, 2017 
Cox CF (2017) Sensory mechanisms in dentine: A literature review of light microscopy (LM), transmission microscopy (TEM), scanning microscopy (SEM) \& electro physiological (EP) tooth sensitivity: Is the ciliary organelle on the odontoblast the elusive primary nociceptor?

the people... received at first with implicit faith however they became stumbling blocks as civilization advanced... Myths were received at first with implicit faith...Learned men explained these selfsame myths as historical facts disguised as metaphors, or as moral allegories, which the choice of Hercules undoubtedly is" [11].

Aristotle (384-322BC) from ancient Greece credited Hippocratesthe Father of Medicine (460-370BC) from Kos in northern Greece-who taught his student that tales of demons, evil spirits, foul air, contact with manic humans were false \& to move beyond the ancient consideration of unnatural or supernatural myths of disease by teaching that critically thinking people should use independent thought in all of their actions as well as teaching \& practice in their treatment of infirmities \& pain control of diseases [12].

Who were the early notables to carry out research that resulted in the 3-scientifically based theories of dentine sensitivity as presented in the abstract? What are the strong points of the scientific research that support each theory of dentine sensitivity? What-if any-have been the limitations of LM, TEM, SEM \& EP technologies that have examined dentine sensitivity? What are some possible limitations associated with the various in vitro \& in vivo studies that have examined tooth sensitivity? Is there reliability to the TEM \& SEM studies that suggest cilia are the initial morphological sensory appendages that project from each OP into each dentine tubule as the specific initial nociceptor of the tooth's sensory mechanism? Does any particular clinical study or series of studies support one of the 3-theories of dentine sensitivity over the other theories?

Research has supported a greater part of the published studies of the 3-accepted theories of dentine sensitivity. Yet-even today-there remains an elusive fragment in each theory as to what is the initial nociceptor organelle. We hope our review will prompt colleagues to explore new technologies, in which to investigate the initial nociceptor tooth sensitivity mechanism.

\section{The nerve theory of dentine sensitivity}

Technical advances of tooth LM fixation, demineralization \& thin sectioning allowed staining of nerves in mineralized tissues-\& so it seems only reasonable that innervation of dentine was the $1^{\text {st }}$ scientific theory to attempt to explain dentine sensitivity-based on the gross identification of nerve fibers in tooth pulps. The staining of nerves with gold, silver \& other metals promoted the nerve theory of fine nonmyelinated nerve fibers-in the predentine-dentine tubule interface-in an attempt to explain human tooth sensitivity.

In 1770 John Hunter (1728-1793) was the $1^{\text {st }}$ notable to propose that nerves were responsible for transmitting tooth pain. By 1776 Hunter-a noted Scottish surgeon-spent several years as an Army surgeon \& had become experienced in the clinical treatment of gunshot wounds \& their management \& was appointed physician to King George III. He was recognized for his research of human foetal development, dental surgery \& human tooth transplantation. He became a Fellow of the Royal Society in 1767-receiving the prestigious Copley Medal in 1787 for his contributions [4].

In 1835 Raschkow-using LM-demonstrated that bundles of myelinated nerves ran through the root apex \& into a central pattern where they separated into smaller groups that radiated to the peripheral pulp \& into fine non-myelinated fibers that formed Raschkow's nerve plexus. These fibers spread throughout the peripheral pulp subjacent to the primary odontoblasts with some paralleling the pulp-predentine interface [13].
In 1848 Sir John Tomes (1815-1895)—a distinguished surgeon \& scholar used LM to identify peritubular dentine \& fine non-myelinated nerves in the peripheral pulp [14]. In 1836 John joined the Medical School of King's College in London \& was inducted as a Member of the Royal College of Surgeons \& appointed House Surgeon at Middlesex Hospital. He twice served as President of the Odontological Society. He introduced the routine use of ether for general \& Oral Surgery to his colleagues at Middlesex. In 1858 he encouraged the Royal College of Surgeons to grant licensure to clinicians who held a License of Dental Surgery (L.D.S.). He personally supported the Dentist Act of 1878 to successfully register physicians who were licensed as dentists.

In 1866 Cutler suggested that fine nonmyelinated nerve fibers accompanied the OP into the dentinal tubules-but failed to mention how far the fine nerves could be observed [15]. These observations were $1^{\text {st }}$ corroborated by Boll in 1868 who used chromic acid staining to show nerve fibers entering into the dentine tubules [16].

In 1896 Morgenstern showed dense meshwork's of nerve fibers that traversed the predentine-dentine interface in all directions \& lodged along the dentine tubule interface. He believed that fine nerve fibers in the dentine tubules were initial pain receptors $[17,18]$. In the 60 -years from the 1890's to the 1960's researchers of oral tissues made many technical advancements of LM fixation, embedding, sectioning \& staining. In 1917 Mummary modified a gold stain to identify pulpal myelinated nerves to the odontoblasts \& reported that OP's formed a "brushwork of fibrils" that synapsed with the cells [19].

In 1927 Toyoda demonstrated silver impregnated nerve fibrils in the dentine tubules \& regarded them as specialized nerve endings when lying adjacent to OP's [20]. In 1934 Toyoda detailed many types of fine silver-stained nerve fibrils in the dentine tubules-describing them as specialized nerve endings [21]. Others (Brashear, Bradlaw \& Bernick) demonstrated nonmyelinated nerve fibers in the predentine $\&$ revealed-with quality tissue processing \& photomicrographs-the presence of fine nonmyelinated nerves in the dentine tubules [22-24].

In 1957 Fearnhead employed the Holmes silver stain technique \& showed nerve fiber innervation of human dentine. His controlled laboratory procedures "demonstrated very small beaded intra-tubular nerve fibrils in human dentine having an approximate diameter of $0.2 \mu \mathrm{m} . .$. situated in the tubules between the odontoblast process and tubule wall...traced in continuity from the predentine into the tubules for varying distances up to $0-4 \mathrm{~mm}$." Fearnhead mentioned that histological techniques "impose a quite definite limitation on interpretation, which is [often] overlooked during the excitement of discovery...it must be remembered that the presentation of morphological investigations alone cannot explain the mechanism of dentine hypersensitivity." In his studies, he used controlled histological methods to exclude sources of artifact, which had previously led some colleagues to suggest misinterpretation of the silver impregnated fibrils [25].

At the 1962 London Sensory Mechanisms in Dentine Symposium, Arwill gave an erudite review of the morphological aspects of dentine innervation-noting, "myelinated nerves accompany blood vessels \& continue towards the pulp-predentine interface where they send out fine non-myelinated fibers with free nerve endings that lie in contact with the odontoblast processes". Arwill noted the issue of nerve staining was based on the affinity of silver to stain the fibers without being compromised by artifacts. He proposed 8-patterns of non-myelinated nerve fibril distribution in human dentine [26]. 
Cox CF (2017) Sensory mechanisms in dentine: A literature review of light microscopy (LM), transmission microscopy (TEM), scanning microscopy (SEM) \& electro physiological (EP) tooth sensitivity: Is the ciliary organelle on the odontoblast the elusive primary nociceptor?

1- Nerve fibrils that spiral around the OP \& end on the surface of the OP.

2- Nerve fibrils that follow a direct course to the OP \& end as swellings on the process.

3- Nerve fibrils that terminate on the surface or within the body of the odontoblast.

4- Nerve fibrils that ran within the OP.

5 - Nerve fibrils lying free \& end in the odontoblastic zone with no direct contact with OP.

6- Nerve fibrils cross the OP \& run in the non-mineralized predentine ground substance.

7- Nerve fibrils that spiral around the OP \& run in the predentine ground substance.

8- Single nerve fibrils that ran in separate canals.

In 1976 Itoh used a silver-nitrate stain to show Raschkow's marginal nerve plexus in the peripheral pulp. The marginal layer was commonly seen in permanent teeth but only occasionally in primary teeth. He classified 3-types of nerve fibers [27].

1- Nerve fibers-he called sensory-ran to the predentine-dentine mineralization front \& paralleled the dentine tubule interface.

2- Nerve fibers that ran obliquely along or transversely into the predentine.

3- Nerve fibers that ran to the predentine-dentine border \& looped back to the odontoblast layer.

In 1983 Gunji used LM, TEM \& SEM data to show myelinated \& non-myelinated nerve distribution in human tooth pulps describing the delicate microscopic details of organized neural patterns within the sub-odontoblastic, odontoblastic, predentine with limited fiber penetration into the dentine tubules-not exceeding $100 \mu \mathrm{m}-$ in agreement with the 1973 TEM publication of Corpron \& Avery [28]. Gunji suggested an intimate mechanoreceptor complex theory to explain a nerve-odontoblast interrelationship within the $1^{\text {st }} 100 \mu \mathrm{m}$ of the odontoblast-predentine border.

Gunji, et al. evaluated non-carious human pulps from 8 to 60 -years. They noted increased nerve density-until 30-years-suggesting increased dentine sensitivity thru eruption to function. Their data demonstrated non-myelinated nerves-they called sensory-terminating as free-nerve endings \& distributed as 4-morphological subtypes, similar to the histological observations of Arwill, Fearnhead \& Itoh.

1- Nerve fibers ran from Raschkows marginal plexus thru the cell-free \& odontoblasts, but did not project into the tubules beyond the predentine interface.

2- Simple nerve fibers ran thru the odontoblastic layer-some in close contact with OP's-\& occasionally ending in the predentine. Single fibers ran transversely thru the odontoblast-predentine zone \& some looped back to the odontoblasts.

3- Complex nerve fibers coursed thru the predentine \& branched horizontally in many directions over thousands of square $\mu \mathrm{m}$ as a complex terminal apparatus along the cervical pulp with no definitive territorial regions.

4- Fine single nonmyelinated fibers passed thru the odontoblastpredentine zone-only to the dentine interface \& never ran transversely.
Gunji's TEM observations revealed nerve fibers that were often seen as naked nonmyelinated axons \& always filled with neurofilaments, neurotubules, mitochondria \& associated with nerve swellings. Gunji noted they never observed tight or gap junctions between the odontoblasts, their processes or with nerve fibers in the tubule complex. He noted that OP were generally poor in intracellular organelles. Swellings of nerve fibers were always seen associated with an OP at their meeting juncture with an intervening space of from $150 \AA$ to $300 \AA$, which Gunji noted was similar to chemical synapses of other tissues. TEM verified LM variations \& degrees of simple \& complex nerve fiber distribution \& SEM revealed beaded-like swellings [29,30].

\section{The hydrodynamic fluid flow theory of dentine sensitivity}

The observation of fluid in the dentine tubule complexespecially following clinical restoration-often heightened patient hypersensitivity following distortion of fluid on the cavity wallsprompted fluid flow as the $2^{\text {nd }}$ scientific theory of dentine sensitivity.

In 1842 John Neill (1819-1880) $1^{\text {st }}$ proposed a fluid deformation theory in the dentine tubules as the cause of tooth sensitivity. John passed the admission examination to The Univ. of Penn. at 13-years of age. After graduating in 1837 with a Master of Arts (A.M.) degree, he entered the Univ. of Penn. Medical Department \& graduated with an M.D. at 18-years. Noteworthy of Neill's contribution to dentistry was his 1842 graduate thesis on "Sensibility of the Teeth explained on Hydrostatic Principles" in the Med. Examiner Jour. [31] \& his 1850 publication in the Am. Jour. of Med. Sci. His articles were the $1^{\text {st }}$ to offer a scientific explanation due to fluid sensitivity. In his 2-dental publications Neill wrote: "Each tooth has three textures...Although very compact...dentine consists of numerous fine dental tubuli, the average diameter of about $1 /{ }_{4170}^{\text {th }}$ of an inch. These tubules are larger at their commencement...opening at the pulp-cavity...They radiate in nearly parallel lines, and their finest ramifications sometimes terminate in minute cells or loops at the enamel-dentine junction...Their tubular character is proven by the passage of ink and other fluids along them... The intertubular substance is translucent and finely granular...Dentine does not contain blood vessels or nerves but consists of 28-parts of animal, and 72-parts of earthy matter...The principal components are gelatin and phosphate of lime-containing neither blood vessels nor nerves...Tubules are filled with a fluid secreted by the pulp and if the tubules thus filled with fluid pass from the circumference of the $E D J$ to the interior of the teeth-then may not pressure applied without by compressing on the enamel and the fluid of the tubules-then affect the nervous pulp within, by subjecting the pulp to a species of hydrostatic pressure the amount of which can be measured...whatever reduces the thickness of enamel or uncovers any portion of the tubules of dentine, thus increases the painful impressions caused by external pressure [excavator]...Thus acid by removing the mucous, by which the teeth are ordinarily covered \& perhaps a portion of the enamel as well, thus increases their sensibility to external impressions...it is the expansion and contraction of the fluid in the tubules of the dentine, compressing the nervous pulp...causing it to expand in the other, to fill the partial vacuum formed in each tubule" [32].

Alfred Gysi (1865-1957) was born in Aareu Switzerland \& showed strong scholarship as a young lad. At 16-years he began dental studies in Geneva \& completed his D.D.S. at Univ. of Penn. Dental College in 1884 \& his Ph.D. in 1887. He completed his Federal Dentistry Diploma at Zurich in 1889 \& became co-founder of The Zurich Dental Institute \& Professor of Prosthetics at Zurich in 1931. Gysi was the $1^{\text {st }}$ dentist to 
Cox CF (2017) Sensory mechanisms in dentine: A literature review of light microscopy (LM), transmission microscopy (TEM), scanning microscopy (SEM) \& electro physiological (EP) tooth sensitivity: Is the ciliary organelle on the odontoblast the elusive primary nociceptor?

receive the Swiss Science Marcel Benoist Award in 1925 for scientific contributions. Gysi was a noted prosthodontist who invented an articulator that remains used today.

Gysi published his clinical observations regarding the fluid theory of dentine sensitivity An attempt to explain the sensitiveness of dentine in the 1899 Brit. J. Dent. Res. [7] - the theory was later validated in 1963, 1964 \& 1978 by the scientific research of Brännström (19222001). During that era, some colleagues believed dentine sensitivity was due to the stimulation of nerve fibers in human dentine tubules. Others maintained that dentine sensitivity resided in the OP, which extended the length of the dentine tubule complex as the initial sensory stimuli \& conveyed to the sub-odontoblastic nerve plexus \& the brain as pain. Gysi wrote in his daily clinical records, that during gentle removal of the outer infected soft carious dentine-before local anesthesia \& dental engines were commonplace-he would periodically stop to provide the patient momentary relief from drilling with steel burs. Upon returning to the cavity, he observed fluid on the cavity floor \& during its removal with a dry wick, some patients complained of a sharp painful reactiongaining relief when he rapidly removed the moist wick. From his clinical observations, he realized that the rapid drying of fluid from the cavity floor disrupted the fluid of the dentinal tubule complex-giving support to Neill's 1842 theory of fluid dynamics in vital dentine. While a professor at Zurich in 1894 he built a microphotography camera for nightlong exposures of the $1^{\text {st }}$ published photomicrographs of the developing human enamel-dentine-pulp interface [33].

Martin Brannstrom (1922-2001) was born in Burstrack Sweedon $\&$ raised by his grand mom after his mother died when he was 6-years old. He completed his doctorate in Stockholm in 1962 with his thesis written on the mechanism of human dentine sensitivity. His publications presented scientific data in a clear understandable manner for clinicians to use in their clinical practice.

In the early 1960's Brännström began his biological \& clinical studies at Karolinska Institute with Dr. Nyborg-his mentor in pulp histology. During the following years, he demonstrated-that microleakage of oral microörganisms \& their toxins were the main cause of pulp inflammation. His clinical research demonstrated-the hydrodynamic fluid flow in dentine was a fact-not just a theory. Martin explained that many publications, which had condemned acidic cements, were based on faulty methodology to stain for bacteria in any tissue sections, had confounded their conclusions. Brännström's clinical studies confirmed Neill's \& Gysi's theories-that fluid flow movement was the rapid cause of dentine sensitivity \& that sensitivity was treatable if the clinician could understand \& diagnose the cause. Within 2-decades, Brännström had provided research, which changed the concepts of biocompatibility of restorative agents as well as understanding the nature of dentine sensitivity. Brännström maintained his clinical publication efforts in peer-reviewed journals \& presentations well into the late 1990's.

Brännström developed his research interest in bacterial infection $\&$ dentine sensitivity, especially since a great deal of the literature from the 1940's to the 1970's had condemned restorative materials e.g. acidic components of zinc phosphate \& silicate cements as being toxic to the vital dental pulp due to their low $\mathrm{pH}$. It is important to make note at this point that the clinical \& research data of Dr. Brännström demonstrated a strong relationship that bacterial microleakage along the restoration interface was responsible for pulp inflammation \& hypersensitivity.

During Brännström's visits to The Univ. of Mich. thru the 1980's to the 1990's, he was always forthcoming with his knowledge \& non-confrontational manner to share information with students \& colleagues. Brännström was a true dental notable-his research remains familiar to many colleagues today-making numerous contributions to our profession that have strongly impacted on today's clinical practice, resulting in major benefit to patients worldwide.

Brännström's erudite presentation at a 1962 London Symposium detailed his clinical \& research data on the hydrodynamic mechanism of pain through dentine. He reported his recording of pain in patients during cavity preparation in vital non-carious dentineearlier described by Gysi-was due to fluid distortion within the dentine tubule complex of the cavity. Brännström was $1^{\text {st }}$ to call fluid distortion as a hydrodynamic mechanism that could be treated by providing a hermetic seal to the dentine tubules \& enamel defects as well as any exposed defects that allowed fluid movement within the vital tubules [8]. He followed a year later with data that further supported the hydrodynamic mechanism as the cause of rapid pain due to the distortion of fluid at the dentine tubule interface [34]. In his 1981 textbook, Brännström wrote: "Seeing implies making ourselves free of prejudices, becoming aware of our being manipulated by old frames of reference, acquiring new ones through the collection of knowledge, giving truth priority over the way we would like things to be, interpreting imaginatively so that development forward becomes visible" [35].

\section{The odontoblast process theory of dentine sensitivity}

The $3^{\text {rd }}$ major scientific theory to explain dentine sensitivity implied the OP was the initial nociceptor based on clinical observations of the LM presence of soft-tissue OP that projected from the apical collar of odontoblasts into the tubule complex.

John Tomes published a series of research papers on oral tissues in the Philosophical Transactions Jour. between 1849 \& 1856, which suggested that the OP was the initial sensory receptor. This led to the naming of the OP as "Tomes fibrils" which he was credited by his colleagues \& knighted as Sir in 1866 [6].

Charles Tomes (1848-1928)-eldest son of Sir John Tomeseducated at Radley College \& matriculated to Oxford University \& graduated from Christ Church in 1866 with a Bachelor of Arts (B.A.). He received the highest $1^{\text {st }}$ class honors in the school of Natural Science history-with his name on one of the shortest honors list that had ever been registered at Oxford Univ. In 1859 Charles also speculated that the OP functioned as the primary receptor of dentine sensitivity [36]. His "Manual of Dental Anatomy, Human and Comparative" gained honors in medicine \& surgery in 1869. In 1898 Charles was appointed to represent the General Medical Council of Great Britain to promote recognition of dentistry as a dental profession. He was knighted as Sir Charles Tomes as had been his father's honor.

In 1893 Hopewell-Smith (1865-1919) proposed "the odontoblast [OP] serves as the nerve-end organ with sensitivity being conveyed... as a protoplasmic prolongation of the cell... all nerve-fibers and nervecells are derived from the neural or neuro-sensory epithelium" [37]. Based on his extensive review of the literature, he published the "Noninnervation of Dentine" maintaining that sensitivity was based on the concept that "the pulp fibrilloblast [odontoblast] performed a higher [sensory] function with the transmission of tactile \& other external sensory impulses on the vital pulp surface." His interpretation of the literature noted that staining of nerves was a "misinterpretation of a certain type of artifact that is obtained after modification \& remodification of well-known and established methods and principles of staining, specifically adapted to nerve elements...pointing out that the application of solutions of cocaine hydrochloride when placed 
Cox CF (2017) Sensory mechanisms in dentine: A literature review of light microscopy (LM), transmission microscopy (TEM), scanning microscopy (SEM) \& electro physiological (EP) tooth sensitivity: Is the ciliary organelle on the odontoblast the elusive primary nociceptor?

onto exposed surfaces of normal dentine without pressure has no appreciable effect-therapeutic, obtundant or otherwise...There are no nerves in dentine: the animal economy does not require them in this or any calcified connective tissue... There is, consequently, no sensation in dentine...There is no hypersensitivity of dentine" [38,39]. Imagine if he had lived to observe TEM data demonstrating nonmyelinated nerves in dentine tubules.

In 1933 Tiegs reported that since there remained indefinite data to confirm the presence of nerve endings in the dentine tubules- "it would seem to follow therefore that odontoblasts processes in the dentine must be the receptor organs for the nerve endings; and if they can serve as receptors, then one can at present see no reason for inferring a special innervation of dentine to account for clinical facts, when microscopical evidence does not support it" [40].

In 1958 Avery \& Rapp demonstrated the presence of acetyl cholinesterase on the OP's in human teeth [41]. They implied that Charles Tomes OP sensory theory-100-years earlier-was a most probable theory to explain dentine hypersensitivity based their support of the histochemical acetyl cholinesterase (ACHE) research previously reported by Nachmanson [42]. ACHE is the primary cholinesterase enzyme in the body with high catalytic activity-each molecule of ACHE degrades $\approx 25,000$ molecules of acetylcholine (ACh) \& other choline esters per-second, which function as neurotransmitters. ACHE is found on many types of conducting nerves, but mainly at cholinergic synapses of neuromuscular junctions, than on sensory neurons. From their demonstration of ACHE on the cell membranes of odontoblasts, they speculated that it played a role in the rapid neural conduction of sensory stimuli from the OP to the myelinated sensory nerves of the dental pulp \& rapidly to the trigeminal nerve \& to the brain via the dorsal fibers in the spinal system [43,44].

\section{Electrophysiological studies provide additional insights on dentine sensitivity}

In his opening comments at the 1962 Sensory Mechanisms in Dentine Symposium, Scott stated that EP stimulation was achievable from nerve fibers in the dentine tubule complex. He demonstrated pre-potential signals-also called receptor potential impulse signalshad been recorded from afferent sensory nerves in the dental pulp. Brookhart had previously shown more than 50-bundles of nerve axons entering through the apex to the canine cat tooth pulp using LM [45]. Scott noted "challenges in studying the initial [dentine] receptor mechanism are not being able to see the structures from which we are recording...Consequently [our] pre-potentials of conducted impulses can only be recorded near the receptor unit \& only serve to give a clue to an insight into its mechanism \& its location." Dentine has a complex tubule fluid composition \& unique biological \& deposition of peritubular, intertubular dentine \& collagen assemblage by the odontoblasts. Recording from vital dentine, only a few EP studies have generated meaningful data, due to the complexity of recording from a single nerve fiber in the predentine-dentine tubule complex.

In 1953 Scott, et al. reported they had recorded a single unit potential-using an electrolyte filled electrode-from the dentine of a fully erupted cat tooth following application of heat or cold to the enamel or to the application of slight pressure to vital dentine [46]. In 1953 Scott \& Tempel noted that they could record both action \& receptor potentials of sensory receptor mechanisms that had supposedly originated in the dentine tubules of canines teeth in cats. They suggested the electrical activity of the receptors was compatible with the transducer elements, which were located within the odontoblastic layer or within the proximal predentine region of a dentine tubule [47].
In his concluding remarks, he noted "we have given consideration to the electrical properties of these structures and it is obvious the pulp acts as an electrical conductor. Furthermore, there is a reason to believe that a certain amount of [dentine] tubular conduction may occur."

Horiuchi \& Matthews followed the research techniques described by Scott \& reported "not all of their recorded activity was of biological origin, suggesting that the electrical stimulation of the recorded nerve impulses were artifacts that looked like nerve impulses, which were recorded from the nerves located in the pulp subjacent to the mineralized predentine-dentine substrate and not from the nerves in the dentine tubules...the [Scott \& Tempel] technique was unsatisfactory....Many of the problems seemed to stem from the fact that we were recording from a solid tissue with a very small area of contact between the electrode and electrolyte" [48].

At the same 1962 London Symposium, Yamada reported on a series of experiments, in which he had carefully smooth-shaved enamel \& dentine leaving $\approx 1.2 \mathrm{~mm}$ to $1.5 \mathrm{~mm}$ of remaining dentine to the vital pulp in mandibular teeth of dogs, cats \& rabbits. He was able to obtain "action current readings" on the mandibular nerve $\approx 7$ to $8 \mathrm{~mm}$ distal to the tooth apex. Following application of various chemicals, he speculated that when a stimulus is applied to the OP's in the dentine tubule complex of the remaining dentine, the response was as if it [odontoblast] was a sensory receptor...when the odontoblast is damaged during cavity excavation, it fails to function as a receptor and as such when the chemical agents are applied to the cavity, they only act on the pulp by diffusing through the remaining dentine of the cavity floor...the sensory mechanism of the dentine appears to require the excitation of the odontoblast which conducts the excitation to the pulp nerve" [49].

The 1962 Symposia's concluding remarks by Lord Edward D. Adrian (1889-1977) - the 1932 Nobel Laureate for Physiology \& Medicine-stated "My chief impression of our meeting is that there are many different lines of research on pain from the tooth, which will give valuable results. Clearly the prospect of getting further is very good, in spite of the fact that pain is one of the most difficult sensations to explain, not only by the neurophysiologist, but for philosophers \& even theologians" [50].

In 2006 Allard, et al. published data from their in vitro cell culture model, which employed EP recordings from their novel culture study-using vital odontoblasts from non-erupted human $3^{\text {rd }}$ molars co-cultured with vital cells from rat trigeminal neurons. They demonstrated clusters of $2 \alpha \& 2 \beta$ sodium $\left(\mathrm{Na}^{+}\right)$channel subunits. These sub-unit channels are capable of producing voltage-gated tetrodotoxin-sensitive $\mathrm{Na}^{+}$currents in response to depolarization during voltage-clamp to then generate action potentials. Although their research methodology is very innovative, there was no discussion of their use of other tissues in their co-culture model e.g. had they previously used other co-cultured controls of neurons or odontoblasts or eukaryotic cells from other animals to validate the specificity of their co-localization between a nerve ending from a trigeminal rat neuron that has clustered at a proposed cell-to-cell contact point of a cultured human odontoblast type cells [51].

\section{Clinical reports of fluid movement in the dentine tubules strongly suggest dentine sensitivity is due to hydrodynamic flow}

John Neill was $1^{\text {st }}$ to propose the fluid theory of dentine sensitivity based on the penetration of dye thru enamel \& into the pulp. 
Cox CF (2017) Sensory mechanisms in dentine: A literature review of light microscopy (LM), transmission microscopy (TEM), scanning microscopy (SEM) \& electro physiological (EP) tooth sensitivity: Is the ciliary organelle on the odontoblast the elusive primary nociceptor?

These observations were corroborated in 1951 by Bartelstone who demonstrated the in vivo passage of radiolabelled iodine through intact vital enamel \& dentine to the thymus within 15-minutes after application to the enamel surface [52]. Fifty years after Neill's 1842 thesis-Gysi $1^{\text {st }}$ reported the clinical nature of fluid movement from the cavity floor as the cause of human tooth sensitivity [53].

Clinical data from Orban recorded tooth hypersensitivity in pilots when atmospheric pressure changed from sea level to high altitude (hypobaric pressure) \& also in pilot's teeth when observed in hypobaric chambers. Orban's data was clinically pertinent to explain the hydrodynamic sensory mechanism of dentine sensitivity proposed by Neill, Gysi \& Brännström. Orban reported that normal teeth in pilots showed no tooth hypersensitivity at high altitude flights or in a hypobaric chamber. Whereas pilots reported severe tooth hypersensitivity in teeth restored with leaky amalgam fillings when flying at altitudes from $\approx 5,000$ to 38,000 feet [54]. Consequently, standardized hypobaric flight training was required for pilots who would fly at altitudes $\approx 4,000$ feet above sea level. Their painful hypobaric chamber response was very similar to that experienced by pilots during their actual high altitude flying. Upon further study, Orban was able to correlate the clinical records by noting that pilots who had experienced a recently restored tooth that had been filled with a oxyphosphosphate cement or varnish would often report painful tooth hypersensitivity when observed in a hypobaric chamber. When these leaky amalgam restorations were restored with a $\mathrm{ZnOE}$ base, no tooth hypersensitivity was reported-due to the eugenol-when pilots were observed in a low atmosphere hypobaric chamber or during actual high altitude flying.

Based on the clinical research of Orban, Ritchie \& Harvey-the US armed forces dental corps were instructed to routinely place a $\mathrm{ZnOE}$ base underneath all restorations during preflight treatment. Teeth with normal vital pulps presented no patient discomfort or pain during hypobaric decompression or during high altitude flights [55,56]. It is interesting that the clinical observations \& publications of Orban, et $a l$. have been overlooked from many publications that have reviewed the mechanisms of dentine sensitivity. Orban's hypobaric studies have been validated by Rajpal, et al. [57].

Brännström's pulp biology research demonstrated that the phosphoric acid in various restorative cements \& in acid-etchantspart of most adhesive resin systems-will etch the mineral debris in the smear layer \& debris plugs in the dentine tubules $[34,35]$. Consequently, if the entire restorative interface is not properly sealed, an increased bidirectional flow of tubule fluid will result-especially when the patient is experiencing cold air or ice distortion of the tubule fluid resulting in dentine hypersensitivity.

Home remedies of essential oils e.g. clove, peppermint or eugenol-handed down thru family generations-were known to have the capacity to relieve dental pain. These remedies were well known by an elder family member who had received the knowledge of early people-without any access to professional treatment. They moistened fibers of wool, cotton in an essential oil \& packed it into the carious tooth lesion, which usually gave pain relief \& sometimes even halted the progression of the carious lesion.

The 1975 in-vivo research by Ozeki demonstrated that when ascending concentrations of eugenol were placed into aquaria containing freshwater crayfish-there was an increasing depolarization of motor nerve fibers, which rendered the crayfish lethargic \& they eventually lost all motor control. This study demonstrated that various concentrations of eugenol-when placed in aquaria water-acted as a general anesthetic to render the crayfish completely immobile until the water was freshened \& returned to normal. As the crayfish recovered, they sustained no long-term physiological damage to their normal bodily functions [58].

Since the early 1990's, published in vivo studies by international fishery companies have shown the capacity of various essential oils e.g. clove \& eugenol do-in fact-provide physiological semi-sedation \& stress relief as well as fungal $\&$ bacterial suppression during their longterm transportation of freshwater crustaceans as well as saltwater fish \& lobsters destined for worldwide commercial markets [59-61].

\section{TEM publications of nerves in pulp \& dentine}

In 1952 Bernick (1915-1989) published meticulous TEM data of tooth tissues. Bernick was born in St. Paul MN \& studied anatomy \& pathology \& received his B.S. degree from the Univ. of Minnesota. After serving in the U.S. Navy, Sol spent time at the Armed Forces Institute of Pathology in Washington DC \& then moved to Los Angeles to join Bavetta at USC Dental School to complete his Ph.D. He was appointed as instructor in histology \& promoted to full Professor in 1965 . He published his $1^{\text {st }}$ paper in the J Dent Res in 1942 \& 9-more by 1949 becoming recognized for research on the LM \& TEM innervation of human pulp \& dentine; on the inflammatory reaction; tumor genesis; the embryonic formation of teeth \& associated structures \& lymphatic's. Dr. Bernick became recognized as an international authority on tooth tissues due to his meticulous TEM research: Electron Microscopy of Enamel \& Dentin in the J Am Dent Assoc \& the Electron Microscopy of Carious Dentin in the J Dent Res-the $1^{\text {st }}$ TEM studies to describe normal \& pathological changes in carious dentine, which had not been previously detailed by LM histology [62,63].

We have endeavored to provide critical insight regarding the research of those early notables who published their observations regarding the 3-main theories of dentine sensitivity-each theory having certain credibility. However, science still remains at an impasse to identify the initial dentine nociceptor mechanism that connects to the sensory fibers in the vital pulp. The Table summarizes significant publications on histological \& clinical research, which considers the anatomy \& physiology of dentine sensitivity of each theoryinnervation (Hunter 1770), fluid distortion in the dentine tubule (Neill 1842) \& Tomes odontoblast fibril (J. Tomes 1850) distortion. EP studies have recorded receptor units on vital dentine-suggested as being located in the odontoblastic layer \& predentine region.

\section{The ciliary organelle joins the primary nociceptor controversy}

The cilium organelle (Latin=eyelid) - has been known to science for almost 500-years- $1^{\text {st }}$ observed by Anton von Leuwenhoek, circa 1674. Until the 1960's cilia were generally considered as vestigial structuresdue to the limits of optical LM technologies [64]. In 1898 Zimmerman named these organelles as "centralgeissel for central flagella" [65]. Cilia were originally defined by their capacity to provide movement to unicellular organisms e.g. paramecium at speeds of $\approx 1 \mathrm{~mm} / \mathrm{sec}$ in their pond-water environment. In addition, cilia could stir their surrounding extracellular milieu for food as well as to sense obstacles in their environment for defensive evasion. In 1968 Sorokin proposed that primary cilia were an unusual class of non-motile organelles [66].

\section{Are odontoblast cilia the initial mechanosensory nociceptor?}

In consideration of the recent publications on the sensory capacity of cilia, we offer additional insight into recent ultrastructural data, which implicates primary ciliary organelles projecting from the apical 
Cox CF (2017) Sensory mechanisms in dentine: A literature review of light microscopy (LM), transmission microscopy (TEM), scanning microscopy (SEM) \& electro physiological (EP) tooth sensitivity: Is the ciliary organelle on the odontoblast the elusive primary nociceptor?

Table 1. Sensory mechanisms in dentine.

\begin{tabular}{|c|c|}
\hline Dentist clinician & Observation \\
\hline $\begin{array}{l}\text { Dr. A. Coppa } \\
\text { \& colleagues } 2006\end{array}$ & $\begin{array}{l}\text { Neolithic graveyards (circa 7,000 BC) of the Indus Valley show primitive dental evidence of holes drilled in 11-molars of 9-individuals-possibly } \\
\text { with a bow-flint-head drill-tip-in a crude attempt to treat tooth pain [1]. }\end{array}$ \\
\hline $\begin{array}{l}\text { Homer } \\
5,000 \mathrm{BC}\end{array}$ & Wrote about the supposed presence of tooth worms in teeth that were thought to be the cause of tooth pain as well as tooth decay [2]. \\
\hline $\begin{array}{l}\text { Anton van Leeuwenhoek } \\
\mathbf{1 6 7 4}\end{array}$ & $\begin{array}{l}\text { Reported to the Royal Society on the nature of unicellular organisms - some of which possessed the capacity of rapid mobility due to the presence } \\
\text { of fine hair-like appendages }[3,64] \text {. }\end{array}$ \\
\hline $\begin{array}{l}\text { Dr. John } \\
\text { Hunter } \\
\mathbf{1 7 7 8}\end{array}$ & $\begin{array}{l}\text { A noted Scottish surgeon \& scholar of human fœtal \& postnatal oral development. He was the } 1^{\text {st }} \text { notable to propose that nerves in the central tooth } \\
\text { pulp were responsible for transmitting pain [4]. }\end{array}$ \\
\hline $\begin{array}{l}\text { Dr. Otto F. } \\
\text { Müller } 1786\end{array}$ & It has been suggested by Dr. Bloodgood in 2009 [72,73], that Müller was the $1^{\text {st }}$ individual to use the term of cilia for these organelles. \\
\hline $\begin{array}{l}\text { Dr. Isaacus } \\
\text { Raschkow } \\
\mathbf{1 8 3 5}\end{array}$ & $\begin{array}{l}\text { Identified central pulp nerves that lost their myelin \& ran to the periphery as "Raschkow's subodontoblastic plexus" as nonmyelinated fibers \& } \\
\text { passed to the basal end of the odontoblasts [13]. }\end{array}$ \\
\hline $\begin{array}{l}\text { Dr. Anders A. Retzius 1892, 1893, } \\
1894\end{array}$ & $\begin{array}{l}\text { Used a Golgi silver nerve stain-he \& Isaacus Raschkow showed fine nonmyelinated free nerve fibers that ran thru the periphery of the vital pulp \& } \\
\text { ended in \& amongst the odontoblastic cell layer. }\end{array}$ \\
\hline $\begin{array}{l}\text { Dr. John } \\
\text { Neill } 1842\end{array}$ & Was the $1^{\text {st }}$ notable to postulate that tooth sensitivity was due to fluid distortion in the dentine tubule complex $[5,31,32]$. \\
\hline $\begin{array}{l}\text { Dr. [Sir] John } \\
\text { Tomes } \\
\mathbf{1 8 4 8 , 1 8 5 9}\end{array}$ & $\begin{array}{l}\text { Speculated that "dentine has no inherent sensibility on its own...dentine owes its sensation to the presence of the dentinal fibrils cannot be readily } \\
\text { doubted...pressure made upon the fluid in the exposed ends of the tubes is felt by the pulp at their extremities" }[6,14] \text {. }\end{array}$ \\
\hline $\begin{array}{l}\text { Dr. Franz Boll } \\
\mathbf{1 8 6 8}\end{array}$ & $\begin{array}{l}\text { Used a chromic (silver nitrate) acid stain to demonstrate the presence of nerves as the nonmyelinated nerve plexus of Raschkow along the pulp } \\
\text { periphery [16]. }\end{array}$ \\
\hline $\begin{array}{l}\text { Dr. [Sir] Charles } \\
\text { S. Tomes } \\
\mathbf{1 8 5 8}\end{array}$ & $\begin{array}{l}\text { Speculated that the odontoblast processes in the dentine tubules functioned as the primary receptor of dentine sensitivity \& transmitted external } \\
\text { stimuli impulses to sensory terminations in the pulp [36]. }\end{array}$ \\
\hline $\begin{array}{l}\text { Dr. [Sir] Alfred Gysi } \\
\mathbf{1 8 5 9}\end{array}$ & Was $1^{\text {st }}$ to report that dentine sensitivity was clinically activated by distortion of fluid on the dentine tubules of the cavity floor $[7,33,53]$. \\
\hline $\begin{array}{l}\text { Drs. A, Kowalevsky, } \\
\text { P. Langerhans \& K. Zimmermann } \\
\text { 1867, 1876 }\end{array}$ & $\begin{array}{l}\text { Were the } 1^{\text {st }} \text { published notables to propose the name for the ciliary organelles as "centralgeissel" meaning a central flagella that were being observed } \\
\text { on eukaryotic cells in mammals especially in human cells, besides just on unicellular pond organisms. Until then cilia were only considered as motile } \\
\text { organelles, but they hypothesized that these cilia were also capable of sensory functions. Their proposal was soon lost in the literature until Sorokin } \\
\text { considered them as "primary organelles"'. }\end{array}$ \\
\hline $\begin{array}{l}\text { Dr. H. Jennings } \\
1899\end{array}$ & One of the $1^{\text {st }}$ notables to discuss that the cilium of eukaryotic cells had the capacity to serve as a sensory organelle [74]. \\
\hline $\begin{array}{l}\text { Dr. M. } \\
\text { Morgenstern } \\
\mathbf{1 8 9 6}\end{array}$ & $\begin{array}{l}\text { Published data that the fine nonmyelinated nerve fibers — seen in the predentine region \& near the mineralized substrate of the dentine tubules- were } \\
\text { the initial sensory pain receptors }[17,18] \text {. }\end{array}$ \\
\hline $\begin{array}{l}\text { Dr. Arthur Hopewell-Smith 1893a, } \\
\text { 1893b, 1916, } 1924\end{array}$ & $\begin{array}{l}\text { He proposed that the elongated OP, which extended into the dentine tubule served as the nerve-end organ of tooth sensitivity. He was adamant that } \\
\text { there were no nerves in dentine simply because other calcified tissues did not require any innervation for sensitivity. "Fibrilloblasts [odontoblasts] } \\
\text { were intimately connected with the transmission of tactile and other impulses to the sensory terminations on the pulpal surface...Nerves do-not enter } \\
\text { into the mineralized dentine tubules." [37,38,39]. }\end{array}$ \\
\hline $\begin{array}{l}\text { Dr. J. Howard } \\
\text { Mummary } \\
1912,1919\end{array}$ & $\begin{array}{l}\text { Used a gold chloride technique to stain fine nonmyelinated nerves that accompanied odontoblast processes into the predentine \& formed a brushwork } \\
\text { of fibrils that allegedly synapsed with nerves. He contributed to the understanding of the dense nature of peritubular dentine [19]. }\end{array}$ \\
\hline $\begin{array}{l}\text { Dr. Baliant Orban } \\
1929\end{array}$ & $\begin{array}{l}\text { Based on his LM staining of human tooth tissues, Orban defined the dense stained area at the predentine interface - evident on the apical neck of } \\
\text { odontoblasts \& OP — as a "terminal web" that joined the cells together [54]. }\end{array}$ \\
\hline $\begin{array}{l}\text { Dr. O. } \\
\text { W. Tiegs } \\
1933\end{array}$ & $\begin{array}{l}\text { Used a Bielschowsky silver nerve stain to show some fine fibers that passed thru the odontoblast \& predentine zone \& terminated near or on OP's, } \\
\text { but no fine nerves were seen to run into the dentine tubules [40]. }\end{array}$ \\
\hline $\begin{array}{l}\text { Dr. Hermann Prinz } \\
\text { circa } 1922\end{array}$ & $\begin{array}{l}\text { "It is known that cocaine desensitizes the peripheral ends of sensory nerves... True local anesthetics, i.e. cocaine or its substitutes when applied to } \\
\text { exposed sound dentine without pressure do not produce any pharmacological effect...even if sealed into a fairly deep cavity." }\end{array}$ \\
\hline $\begin{array}{l}\text { Dr. M. Toyoda } \\
\text { \& colleagues } \\
\text { 1934a } \\
\text { 1934b }\end{array}$ & $\begin{array}{l}\text { Used LM, TEM \& SEM to show nonmyelinated nerve fibers that ran from Raschkow's plexus \& passed thru the odontoblast cell zone to form } \\
\text { patterns in an intimate contact with OP's. He suggested that the odontoblast served as a primary mechano-receptor mechanism [20,21]. }\end{array}$ \\
\hline $\begin{array}{l}\text { Drs. Balant Orban } \\
\text { B. Ritchie } \\
\text { \& W. Harvey } \\
\mathbf{1 9 4 5}\end{array}$ & $\begin{array}{l}\text { Demonstrated that sudden acute dental pain was directly associated in restored teeth of pilots who flew at heights above } 4,000 \text { feet or were placed in } \\
\text { barometric chambers with low atmospheric pressure. Normal noncarious or nonrestored teeth did not present any tooth sensitivity in pilots. These } \\
\text { data support the hydrodynamic fluid-flow theory [54-56]. }\end{array}$ \\
\hline $\begin{array}{l}\text { Dr. Sol Bernick } \\
1948,1952 \\
1957,1959\end{array}$ & $\begin{array}{l}\text { Used both LM \& TEM to demonstrate the presence of central nerves that passed to form Raschkow's plexus \& then proceed as nonmyelinated nerve } \\
\text { fibers that ran into the predentine zone of human teeth }[24,62,63] \text {. }\end{array}$ \\
\hline $\begin{array}{l}\text { Drs. D. Scott, } \\
\text { J. Brookhart } \\
\text { et al. } 1953,1963\end{array}$ & $\begin{array}{l}\text { These colleagues were some of the } 1^{\text {st }} \text { research groups to record electrophysiological response patterns from the sensory nerves in the tooth pulps } \\
\text { caused by heat \& other stimuli [45-47]. }\end{array}$ \\
\hline $\begin{array}{l}\text { Drs. M. Watson \& J. K. Avery } \\
1954\end{array}$ & $\begin{array}{l}\text { Using TEM of human teeth tissues, they were able to identify a dense stained zone on the apical region of odontoblasts that they called "a predentinal } \\
\text { border apparatus" [54,104]. }\end{array}$ \\
\hline $\begin{array}{l}\text { Dr. J. J. Philipp } \\
1955\end{array}$ & arious nerve stains he suggested that the odontoblast process served as the primary receptor of tooth sensitivity. \\
\hline
\end{tabular}


Cox CF (2017) Sensory mechanisms in dentine: A literature review of light microscopy (LM), transmission microscopy (TEM), scanning microscopy (SEM) \& electro physiological (EP) tooth sensitivity: Is the ciliary organelle on the odontoblast the elusive primary nociceptor?

\begin{tabular}{|c|c|}
\hline $\begin{array}{l}\text { Dr. F. R. Shroff \& colleagues } \\
\text { 1956. }\end{array}$ & $\begin{array}{l}\text { Examined TEM replicas of shadowed dentine to show several layers of odontoblast process - they suggested that odontoblastic processes function } \\
\text { as some type of sensory receptor cell. }\end{array}$ \\
\hline $\begin{array}{l}\text { Dr. Ronald W. Fearnhead } \\
1957\end{array}$ & $\begin{array}{l}\text { Used Holmes silver stain to show } 0.02 \mu \mathrm{m} \text { nerve fibers that ran into the predentine for several } \mathrm{mm} \text {, however the fine fibers did not run into the dentine } \\
\text { tubules, but looped around \& ran back to the odontoblasts [25]. }\end{array}$ \\
\hline $\begin{array}{l}\text { Drs. James K. Avery \& } \\
\text { Robert Rapp } \\
\text { 1958, } 1972\end{array}$ & $\begin{array}{l}\text { Demonstrated the presence of acetyl cholinesterase on odontoblast processes of human teeth-speculating that ACHE played a role as a } \\
\text { neurotransmitter of sensitivity from the odontoblast processes to the subjacent nonmyelinated nerve fibers [41-44]. }\end{array}$ \\
\hline Dr. A. Sorokin 1968 & He is the notable who renamed the centralgeissel flagella as a primary cilia —other than a non-motile organelle — with sensory capacity. \\
\hline $\begin{array}{l}\text { Dr. M. Yamada } \\
1963\end{array}$ & His EP research reported the excitation of shaved \& exposed dentine when it was stimulated by the chemical means [49]. \\
\hline $\begin{array}{l}\text { Drs. P. Garant } \\
\text { F. Eifinger } \\
\text { C. Cox \& } \\
\text { M. Turchi } \\
\text { 1968, 1970, 1974, } 1983\end{array}$ & $\begin{array}{l}\text { These colleagues published TEM data that showed ciliary organelles that protruded from the apical neck of the odontoblast cell in the area of the } \\
\text { predentine of mammalian teeth \& into the apical opening of the dentine tubule-adjacent to the OP. These cilia were noted to have a continuous outer } \\
\text { membrane that was unbroken with that of the outer odontoblast cell sheath [67-70]. }\end{array}$ \\
\hline $\begin{array}{l}\text { Dr. Tore Arwill } \\
\& \text { colleagues } \\
1963,1967 \\
1968,1973\end{array}$ & $\begin{array}{l}\text { Used LM \& TEM to demonstrate nerves in the predentine region \& suggested 8-patterns of nonmyelinated nerves that were associated with } \\
\text { odontoblasts \& their processes that ran into the predentine-no nerve fibers were observed to run into the dentine tubules [26]. }\end{array}$ \\
\hline $\begin{array}{l}\text { Dr. Martin } \\
\text { Brännström } \\
\text { 1960b, } 1964 \\
\text { 1966, } 1968\end{array}$ & $\begin{array}{l}\text { Reported clinical \& physiological observations that fluid movement in human dentine - due to cold or ice as well as rapid drying of tubule fluid- } \\
\text { caused a Hydrodynamic fluid deformation mechanism — resulting in a rapid response of acute sensitivity to the patient }[8,34,35] \text {. }\end{array}$ \\
\hline $\begin{array}{l}\text { Dr. R. M. } \\
\text { Frank } \\
\mathbf{1 9 6 8}\end{array}$ & $\begin{array}{l}\text { Using TEM, he showed the ultrastructural relationship between odontoblasts, their OP \& fine nonmyelinated nerve fibers. He also contributed data } \\
\text { to define the biochemical formation of peritubular dentine. }\end{array}$ \\
\hline $\begin{array}{l}\text { Dr. F. Eifinger } \\
1969\end{array}$ & $\begin{array}{l}\text { His TEM research demonstrated cilia protruding from the odontoblast \& speculated that these sensory organelles served as mechano-nociceptors } \\
\text { for dentine sensitivity [10]. }\end{array}$ \\
\hline $\begin{array}{l}\text { Drs. S.Takuma } \\
\& \text { N. Nagai } \\
1971\end{array}$ & Using TEM, they reported on the presence of a dense "terminal web" in the odontoblastic zone of odontoblasts in young human premolars. \\
\hline $\begin{array}{l}\text { Dr. Richard } \\
\text { E. Corpron \& } \\
\text { James K. Avery } 1972\end{array}$ & $\begin{array}{l}\text { They showed non-myelinated nerve fibers that ran from Raschkow's marginal nerve plexus, which branched \& then passed through the cell-free } \& \\
\text { odontoblast cells into the predentine region \& then ran thru the predentine \& dentine tubules for no more than } 100 \mu \mathrm{m}[28] \text {. }\end{array}$ \\
\hline $\begin{array}{l}\text { Drs. H. Horiuchi } \\
\text { \& B. Matthews } \\
\mathbf{1 9 7 4}\end{array}$ & $\begin{array}{l}\text { They gently shaved cat enamel \& dentine with a fine diamond \& then applied a } 2-5 \mathrm{~mol} / \mathrm{l} \text { of } \mathrm{NaOCl} \text { electrolyte to the exposed dentine } \& \text { recorded a } \\
\text { spontaneous discharge of electrical impulse [48]. }\end{array}$ \\
\hline
\end{tabular}

1974

Dr. M. Ozeki

Demonstrated the ability of eugenol to serve as a general anesthetic of motor nerves of freshwater crayfish crustaceans then they were placed into a

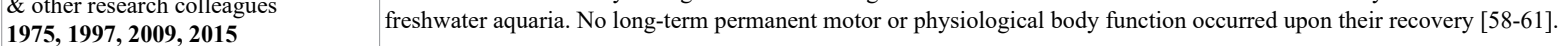

\begin{tabular}{l|l} 
Dr. G. Holland & Using TEM, he reported the presence of specialized areas of membrane contact he called tight junction complexes between odontoblasts [110]. \\
$\mathbf{1 9 7 5}$ &
\end{tabular}

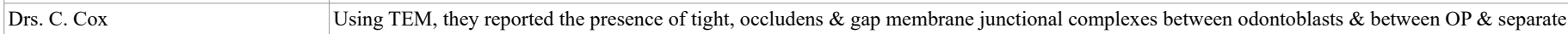

J. Avery, S.Lee et al. 1976

Dr. Katsuhiro Itoh $\quad$ Described nonmyelinated nerves, which ran from the marginal nerve plexus into 3-patterns patterns thru odontoblasts into the predentine. Only a few 1976 fibers had protruded into the dentine tubules for any distance [27].

Drs K. Kelley $\quad$ Demonstrated the presence of odontoblasts_using SEM-in the peripheral region of dentine tubules of nonhuman primate teeth. They also observed G. Bergenholtz a few OP's that had crossed thru the basement membrane during dentinogenesis to become incorporated into the enamel matrix as "enamel spindles" $\begin{array}{lll}\text { \& C. F. Cox. } & \text { [9] } \\ 1982 & \end{array}$

1982

Gunji

\& colleagues

1982, 1983

Drs. Bloodgood, Praetorius, Nauli, Over 23 peer-reviewed publications have demonstrated that the primary cilium organelle as well as some motile cilia (flagella) have the capacity to $\mathrm{Xu}$, Dutcher, \& many others $\quad$ serve as a sensory antenna-like structure, that responds to fluid changes \& to regulate calcium signaling through various protein pathways [65-88].

Dr. Bruno Allard $\quad$ Their research of voltage-gate channels "conferred excitability to human odontoblasts, and strongly suggested that odontoblasts may operate as \begin{tabular}{l|l} 
\& colleagues & Their research of voltage-gate channels "conf \\
sens & sensory cells that initiate tooth pain." [51].
\end{tabular}

Dr. G. Chung

\& colleagues

2013

They suggested additional studies are needed on the molecular mechanisms of dental pain \& should proceed so as to enhance the understanding of

Dr. P. S. Rajpal

\& colleagues

2014 clinical therapies to treat dental pain.

Dr. Y. Shibukawa

\& colleagues

2015

Demonstrated that barotrauma \& barodontalagia are caused by a change in barometric pressure - per Boyles law — that are associated with aviation or scuba diving. Clinicians are cautioned to be aware of tooth fractures or dentine exposure that expose dentine tubules \& to place an anodyne or "bacteriometic" restorations to completely seal the dentine tubules [57].

Their research suggests that an increase in free calcium activates a mechanosensitive-transient receptor potential, which suggests that odontoblasts are sensory receptor cells. 
Cox CF (2017) Sensory mechanisms in dentine: A literature review of light microscopy (LM), transmission microscopy (TEM), scanning microscopy (SEM) \& electro physiological (EP) tooth sensitivity: Is the ciliary organelle on the odontoblast the elusive primary nociceptor?

region of each primary odontoblast-through the predentine \& projecting into the dentine tubule adjacent to the $\mathrm{OP}-$ as a potential initial nociceptor of fluid distortion movement [67-69].

Recent publications have confirmed that primary cilia of eukaryotic cells have the capacity to act as initial sensory fluid shear stress nociceptors. Since the 1960's TEM technology has rapidly surpassed LM resolution-showing that cilia have an internal cytoskeleton of microtubules encased by the cell membrane, which projects a slender antenna-like limb into the extracellular environment. There are estimates of over 1,000 protein complexes that are located in each cilium [70,71] (Figures $1 \& 2$ ).

Each cilium is formed as an outgrowth of the outer plasma membrane of all major eukaryotic cell groups. The outer surface of the cilium is surrounded by the plasma membrane, with assemblage of each cilium beginning during the cell resting interphase. The senior basal body is drawn into a central bundle of microtubules-called an axoneme, of which there are inner \& outer 9-doublet outer-arm (dyneins) that bridge between the microtubules. The basal body is thought to give support to the motile axoneme at the cell membrane. Dyneins are a family of cytoskeletal motor proteins that slide along the microtubules \& convert chemical energy of ATPase into mechanical action. In motile organelles, the small dynein arms drive the beat of cilia or flagella between 5 to 10 times per second. The 9-outer microtubule doublets are connected by a nexin filament that forms a circlet, which surrounds a central microtubule composed of C-1 \& $\mathrm{C}$-2-singlets connected by 2-bridging filament strands with each singlet surrounded by an inner sheath. The A-tubule of each outer doublet contains 3-outer dynein arms \& 2-inner dynein arms along with a radial spoke $\&$ attached spokehead. The B-tubule has no dynein arms or spokes [72-76].

Mechano-sensory ciliary functional capacity has been demonstrated in osteochondrocytes, olfactory, photoreceptor, renal, bone cells \& vascular endothelial cells-having gained attention by many research colleagues $[75,76]$. Praetorius \& Spring have confirmed that most sensory cilia are mechano-sensing organelles, which detect any amount of fluid-shear stress that may pass by the apical collar of the odontoblast [77]-proposing that fluid-flow produces enough

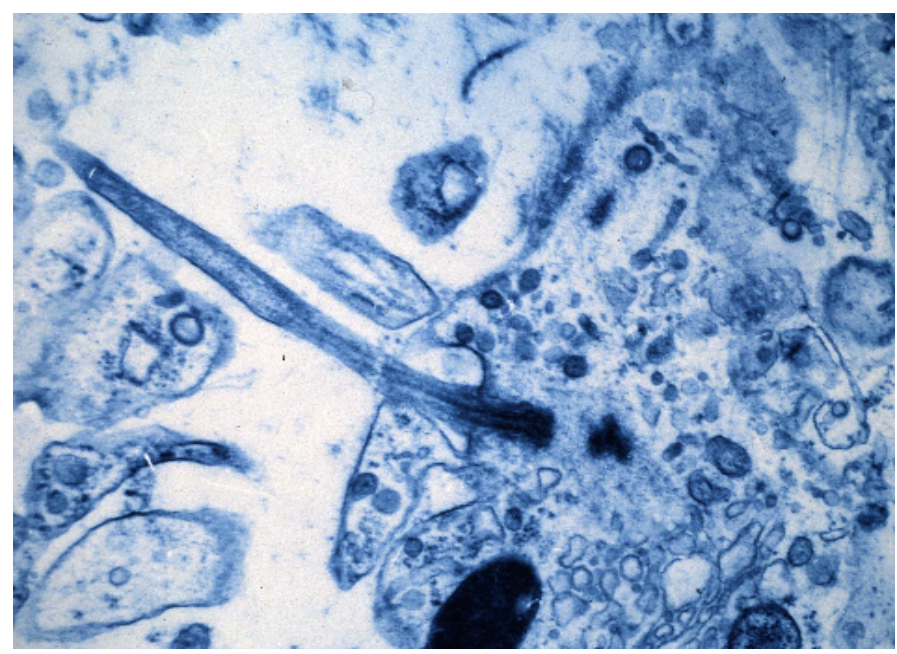

Figure 1. TEM of an adult mouse molar odontoblast. A cilium organelle is seen in continuity with the plasma membrane of the odontoblast cell thru the predentine matrix of the dentine tubule opening. The separate dark stained basal body is seen lying below the centriole base, which lies in continuity with the 2-dense outlines of the doublet tubule microtubules in the ciliary organelle stalk, that protrudes into the lower zone of the predentine tubule [70]. Original X 2,000 .

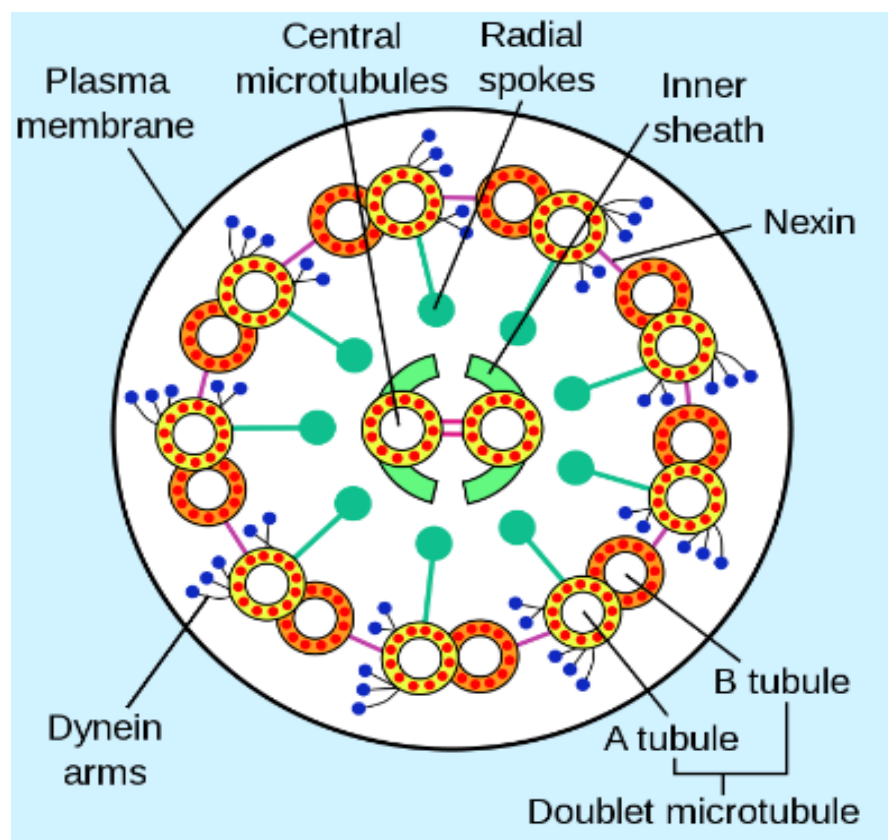

Figure 2. In 1899 Jennings suggested that some motile cilia have a particular biological sensing capacity to monitor local fluid shear stress on the cell membrane. Bloodgood's review-Sanderson \& Dirksen (1986); Evans, et al. (2002); Meyerhof (2005); Ross, et al. (2005); Chandrashekar, et al. (2006) \& Lorenzo, et al. (2006) — that motile \& primary cilia have the ability of sensory perception - supporting our hypothesis that each odontoblast cilium has the nociceptor capacity to react to fluid flow in dentine tubules during mechanical or physiological deformation [72-74].

drag-force along the apical portion of the cell, that causes a bending distortion of the sensory cilium.

The amino acid cystine is a more stable oxidized dimer form of Cysteine-due to its sulfur bonds. Cystine is formed from 2-molecules of cysteine. Cysteine works as an antioxidant \& is found as a component of hair, nails \& skin. Several studies have demonstrated that polycystine-1 \& polycystine- 2 function as part of a mechanosensor complex within the ciliary organelles. Nauli, et al. have demonstrated that polycystine- 2 is localized in primary cilia of endothelial vascular cells in the aorta, which senses fluid-shear stresses [78,79]. They have demonstrated that ciliary polycystine- 2 is a unique shear-sensitive $\mathrm{Ca}^{+}$ channel required to activate a biochemical cascade for nitric oxide production. In addition, they reported that another sensory function of cilia is that any movement of shear sense sensing is mediated through the localization of members of the transient receptor potential of ion channels in which they respond to vibration, touch \& high osmolarity. In addition, primary cilia have been observed to function to sense oscillatory fluid flow generated by mechanical stimuli during dynamic loading [80-87].

Cilia have been shown by TEM to project from the apical region of the odontoblast into the dentine tubule \& may be crucial in both dentine formation as well as the mechanism of pain transmission [88]. From these publications [77-88] odontoblast cilia organelles have been hypothesized as the initial nociceptor to serve as a fluid mechanoreceptor that responds to fluid deformation within the dentine tubule.

\section{Features of closed-static \& open-dynamic biological tubule systems}

In an attempt to consider the innervation \& physiology of various biological organ \& tissue systems, we have attempted to draw some 
Cox CF (2017) Sensory mechanisms in dentine: A literature review of light microscopy (LM), transmission microscopy (TEM), scanning microscopy (SEM) \& electro physiological (EP) tooth sensitivity: Is the ciliary organelle on the odontoblast the elusive primary nociceptor?

comparisons \& differences of certain features of the closed dentine mineralized tubules of the tooth to the various open tubules of the nonmineralized human organ systems e.g. parotid, sublingual \& other salivary glands, which have autonomic secretory functions (Figures $3 \& 4$ ).

The pulpal opening of each dentine tubule permits the odontoblast cell to project its OP into the predentine region \& course distally through each dentine tubule where it terminates at the EDJ during dentinogenesis. From a strict morphological standpoint-the dentine tubule may be considered a closed tubule system in a normal noncarious tooth. With aging as well as during a carious insult or iatrogenic treatment, the tubule may become filled in with the daily deposition of HAp matrix.

Besides the OP \& collagen fibers, the vital dentine tubules contain an extracellular fluid transudate, which is often called dental lymph. It is composed of a pulpal fluid as well as the soluble moiety of the dentine ground substance [91,92]. This fluid may be likened to fluid secretions contained in the human soft tissue open tubule systems. In these organs, the cells have primary cilia that protrude into the lumen of the tubular units, which act as fluid mechano-receptors.

The physiological similarities of a closed tubule system e.g. dentine tubule \& open salivary tubule systems are: both closed \& open systems secrete substances that are released into their extracellular milieu \& are incorporated in the function of body tissues (Figure 5).

The closed dentine tubule system is what appears to be what evolution has selected for-since it engenders dental health \& dentine remineralization. Dentine pain is an early indication of a breach of the

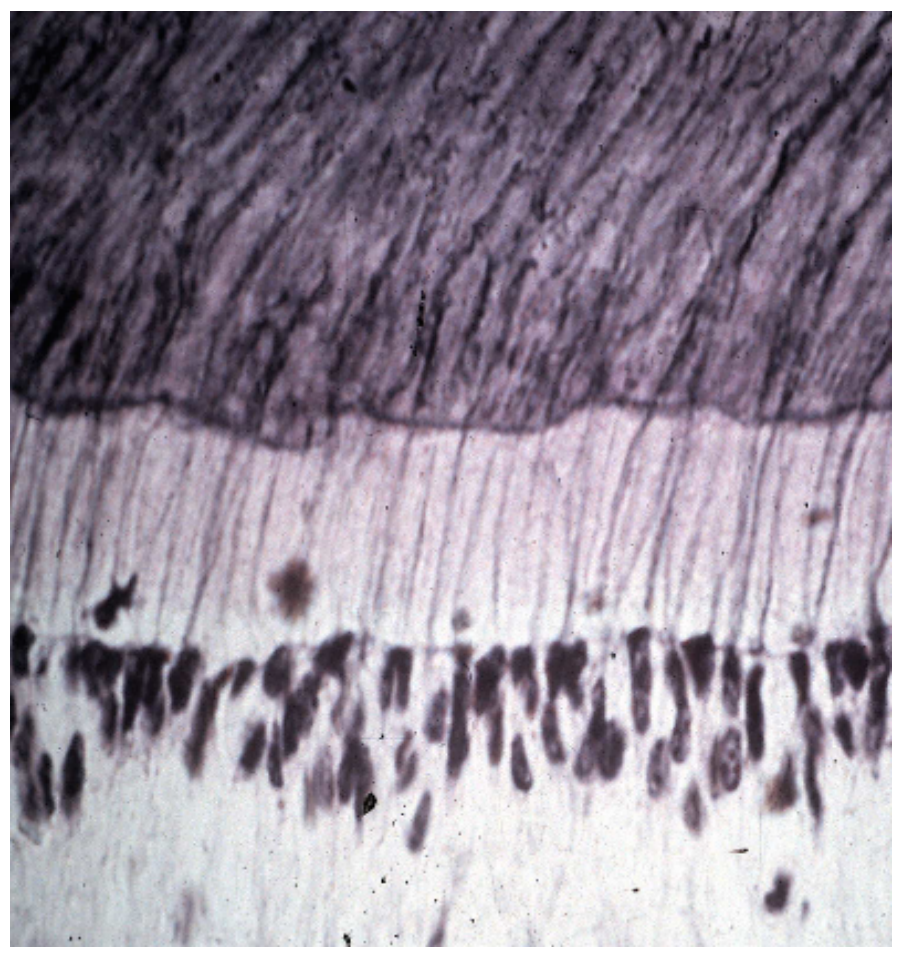

Figure 3. An LM section thru the human pulp-predentine-dentine interface. The clear cellfree zone lies below the primary odontoblasts with dark nulclei in the mid-lower field. The light pink is nonmineralized predentine matrix showing dark stained forms projecting into the dark purple mineralized dentine tubules. OP's project from the odontoblaststhru the predentine - into the mineralized dentine - bound by a dense casing of calcium hydroxyapatite (HAp) peritubular dentine. Normal dentine tubules may be considered a closed non-leaky HAp system. Leaky dentine may cause fluid flow-resulting in dentine sensitivity [7,53-56].

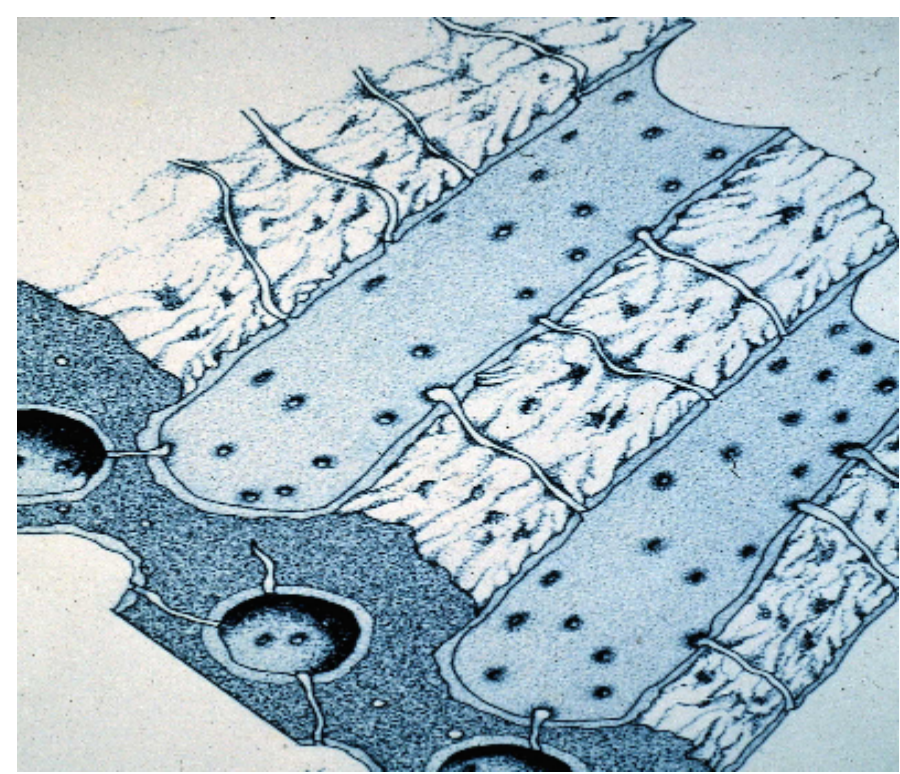

Figure 4. Dentine of the human tooth is a mineralized multi-tubular substrate that contains vital OP's, which are encased in a very dense mineralized peritubular dentine of HAp that encases each tubule, which is essentially collagen-free $[89,90]$. The dark blue en-face (lower left) shows several views thru the intertubular dentine with small interconnecting canaliculi, which permits the flow of fluid to run from one tubule to another. Avery, et al. Oral Histology 1981. Pg. 71.

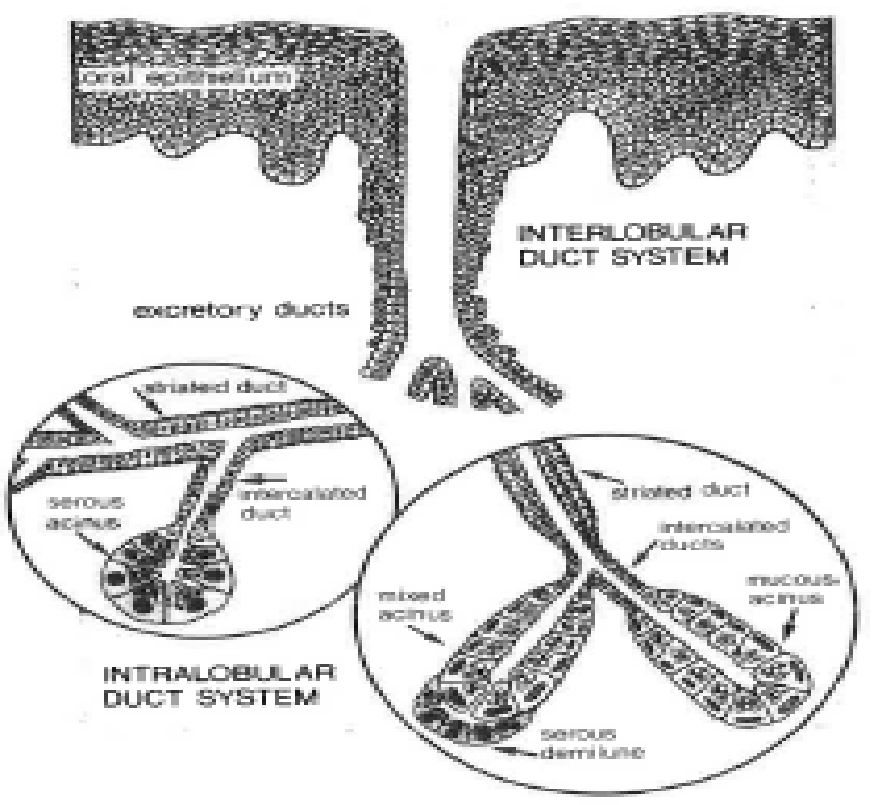

Figure 5. Diagram of an "open" excretory salivary gland unit. These units are ectodermally derived invaginations of oral epithelium that form a proximal serous or mucous acinius composed of secretory cells - often - with outer myoepithelial cells. The proximal acinus secretory system branches into small tubes that lead to intercalated ducts- these run to striated ducts \& then into an excretory duct. These soft tissue glands are innervated by autonomic nerves \& are not encased by any sort of dense HAp mineralized substrate, which would make it a closed system. Avery, et al. Oral Histology 1981. pg. 201.

closed system allowing an open system with resulting movement of tubule fluid. The remineralization of the odontoblastic process at the apical end preserves a closed system throughout life (if possible) \& it also preserves a healthy odontoblast \& pulp. An open dentine tubule system permits ingress of oral bacteria. Early humans needed this essential closed system to prevent pulpal infection from ensuing morbidity/ mortality. Dentine sensitivity indicates open tubules \& oxylate crystals, 
Cox CF (2017) Sensory mechanisms in dentine: A literature review of light microscopy (LM), transmission microscopy (TEM), scanning microscopy (SEM) \& electro physiological (EP) tooth sensitivity: Is the ciliary organelle on the odontoblast the elusive primary nociceptor?

indirect pulp caps, sealing via cohesive hybridization closes them, eliminates pain \& engenders self-healing within the tubule.

Both closed \& open tubule systems are innervated by nonmyelinated nerve fibers. Soft tissue organs \& glands-e.g. salivary-are regulated by postganglionic sympathetic nerve fibers of the autonomic involuntary control system, which supplies the smooth muscle \& glands \& internal organs-acting unconsciously to regulate bodily functions e.g. digestion \& other autonomic processes.

Dentine innervation has been shown to be supplied by nonmyelinated nerve fibers-presumed to be sensory nerve fibersthat pass between the odontoblasts \& run into the nonmineralized predentine region of the proximal dentine tubule. Some colleagues have postulated they are part of initial sensory nociception \& some colleagues have speculated that dentine is innervated by autonomic nerves, which may be responsible for governing odontoblast function $\&$ regulation of dentine deposition [93].

The differences between the closed dentine tubule \& the open tubular organ systems are also known. The closed dentine tubule is completely bounded by a thin dense HAp layer of peritubular dentine (Figure 4). The greater part of the mineralized dentine is an intertubular mineral substrate of $\approx 75 \%$ HAp $\& \approx 25 \%$ collagen with other minor proteins.

From a morphological \& histological aspect, ciliated tubule cells of the human bile duct have been shown to detect fluid-flow stimuli \& to transmit these stress signals, which in turn induces an intracellular $\mathrm{Ca}^{+}$release response. These major soft tissue organ systems may be considered as open biological systems, in which their autonomic innervation (e.g. salivary) receives postganglionic sympathetic fibers nerve fibers that enter the organ with the vessels \& serve to regulate the vascular tone of the organ as well as the secretion of their various fluids-e.g. the juxtaglomerular granular cells of the kidneys. Generally, the cilia of these soft tissue tubule systems act in physiological concert to serve as sensory organelles, which exercise an autonomous cellular management without the central sensory perception system of the dentine tubule.

Regarding human odontoblasts-the close relationship of nonmyelinated nerves that lie in close approximation of the odontoblasts in the predentine region-it has been postulated that besides the nociception of sensory stimuli, another function of the fine nerve fibers nerves in the predentine tubule complex are involved in providing a morphogenetic stimulus to the odontoblasts that may control or modulate the rhythmic deposition of circumpulpal dentine as well as to turn on \& off the reactionary, reparative, new dentine bridging as well as very dense HAp peritubular dentine deposition as part of the continuing aging process [94,95].

A number of TEM publications have shown that eukaryotic cells e.g. odontoblasts have demonstrated ciliary stalks-often projecting from the apical region of vital cells-with a centriole \& basal body below the ciliary organelle, which projects into a tubular stalk \& runs through the predentine region \& into the peripheral portion of the dentine tubule complex [96-99].

Magloire \& Hierck have reported that the ciliary stalks, which project off the apical neck of odontoblasts are unique sensory organelles-with the internal components of the organelle being in constant communication with the odontoblast nucleus \& the other cell organelles by molecular \& metabolic trafficking [100,101]. The odontoblast cilia are organelles that appear as small stalk-like appendages, which project-usually from the apical surface of each cell-like an antenna into the predentine. In most non-dividing cells e.g. odontoblasts-the centrioles of the centrosome migrate to the cell surface, where the parent centriole forms the basal body that anchors the 9-peripheral doublets. Studies demonstrated that the variation in length of each cilium contributes to the transduction sensitivity of the cell. Research shows that ciliary mechanotransduction organelles rapidly perceive signals from extracellular stimuli (photoreceptors, auditory, balance, heat, cold, pressure) \& are a key organelle for most developmental \& physiological processes e.g. olfaction, hearing \& photoreception. The primary sensory cilia (photoreceptor rods \& cones) in the retinal wall lack the central doublet of microtubules. Motile cilia e.g. respiratory \& ependymal-generate leftward fluid flow of mucous \& cerebrospinal fluid in vertebrates.

It is apparent that more research remains to be carried out on the morphological relationships e.g. gap, tight, intermediate junctions between nerves \& the OP to nerves as well as between odontoblasts, which would allow any stimulated 1-odontoblast to rapidly spread its electrotonic message to thousands of connected other odontoblasts-as a rapid fire syncytium $-\&$ on to nerves for communication of sensory stimulation from the initial nociceptor to the higher centers as acute hypersensitivity.

Future research on the biochemical mechanisms of the odontoblasts \& OP as well as on the different intra-ciliary e.g. polycystine \& other specific proteins-that have been demonstrated as unique mechanoreceptor markers of fluid shear-stress mechanisms are also suggested. Hopefully, the information would provide new research data on nerves, cilia \& the hydrodynamic fluid flow-which has been shown to be present in each vital dentine tubule.

\section{Our proposed hypothesis of dentine sensitivity: The odontoblastic layer serves as a biological syncytium of cells connected by gap junctions}

We originally contemplated to develop a review of the rich historical research of the many publications regarding dentine sensitivity, however the last few decades of biochemical data of eukaryotic cellse.g. odontoblasts, which possess a primary sensory cilium (Figure 1) it is obvious that there is strong scientific connection of part of each of the 3-thoeries-which we have attempted to discuss in the following writing.

Syncytium is Greek for (syn=together + kytos=hollow container). In the biological sense, it refers to any group of like cells connected by specialized membrane connections i.e. tight, occludens or gap junctions, which permit the joined cells to function as a single electrical action potential [102]. A classical example of a biological syncytium is the formation of skeletal muscle-in which all of the muscle fibers of the muscle form a functional syncytium by the fusion of thousands of individual muscle cells. Cardiac muscle is another example the rapid coordinated contraction of cardiac muscle cells along their entire length.

A number of published clinical \& research studies-put forward by Neill, Gysi, Brännström \& Orban-have substantiated that the dentine tubule system is responsive to a very slight distortion of fluid movement. We propose the hypothesis that the OP cilium is the initial nociceptor organelle that rapidly transmits the information to the odontoblast proper where it is then rapidly shared with the millions of other odontoblasts by way of gap junctions, which have been demonstrated to connect odontoblasts that allow them to respond in concert as a biological syncytium. 
Cox CF (2017) Sensory mechanisms in dentine: A literature review of light microscopy (LM), transmission microscopy (TEM), scanning microscopy (SEM) \& electro physiological (EP) tooth sensitivity: Is the ciliary organelle on the odontoblast the elusive primary nociceptor?

Research has confirmed: "odontoblasts are a static, postmitotic cell population of cells that are incapable of further cell division" [103]. In order for the odontoblast syncytium to operate in an instantaneous biological \& EP manner, it is necessary to briefly review certain TEM publications that have shown various junctional complexes between odontoblasts, OP's \& supposed nonmyelinated nerves in the predentine region.

In 1954 Watson \& Avery suggested-using TEM—“a predentinal border apparatus", which was their equivalent of Orban's LM terminal bars at the collar of the odontoblast cell along the predentine region where the OP forms a conical ferrule as it extends into the dentine tubule [104,54]. In 1967 Arwill demonstrated the close relationship of nonmyelinated nerve fibers to the OP in the predentine \& dentine of human premolars [105]. In 1968 Frank published TEM data showing electron-dense thickenings of the plasma membranes with a $3^{\text {rd }}$ dense line \& granular material in the intercellular space---he noted was similar to a tight junction attachment [106,107]. In 1971 Takuma \& Nagai used TEM to report the presence of a dense "terminal web in young highly active odontoblasts" [108,109]. In 1975 Holland described "the presence of specialized areas of membrane contact (tight junctions) between odontoblasts were regularly observed" [110]. In 1976 Cox, et al. reported on the presence of tight, occludens \& gap junctional complexes between odontoblasts \& OP [111].

A research challenge by Loewenstein noted "the identification of communicating junctions cannot be made safely on morphological grounds only" [112]. Consequently, in order to further the search for the elusive initial noceciptor we have set forth, it seems obvious that more research needs to be carried out to demonstrate the types \& kinds of junctional complexes between odontoblasts, OP's as well as between the closely associated nonmyelinated-sensory \& / or autonomic —nerves.

We have attempted to present an inclusive review of published LM, TEM, SEM, EP \& biochemical data since the 1960's. To those readers who were hoping to find specific answers to the sensory mechanisms in human dentine-we apologize if you only find more questionshowever that may provide those colleagues to dig-in to the open arena of research \& pursue the unknown gaps in knowledge of what \& how the ciliary organelles are functioning in human dentine sensitivity.

This review has been a challenge to develop in a chronological manner. In doing so, we have raised new questions that we feel need further clarification to identify the initial noniceptor organelle \& the physiological key that turns-on the "sensory sensitivity switch".

\section{Acknowledgements}

Each of the authors owes a collective note of gratitude to the academic research colleagues, family \& friends who have supported each of us throughout our research \& academic years \& have given their personal time \& individual kindness, in which they have continued to encourage each of us throughout our careers.

\section{References}

1. Coppa A, Bondioli L, Cucina A, Frayer DW, Jarrige C, et al. (2006) Palaeontology: early Neolithic tradition of dentistry. Nature 440: 755-756. [Crossref]

2. Lloyd J (2013) Homer: Ancient History Encyclopedia. Homer lived circa 750BC \& wrote poems \& literature of great voyages \& wars as well as "Legend of the Worm".

3. van Leeuwenhoek A (1700) A letter to the Royal Society. Philosophical transactions of the Royal Society of London. Number 265, London, Smith \& Walford.

4. Hunter J (1778) The Natural History of the Human Teeth: Explaining Their Structure, Use, Formation, Growth, and Diseases. Illustrated with Copper-plates. J Johnson pub. $1-128$.
5. Neill J (1842) Sensibility of the Teeth explained on Hydrostatic Principles. Univ. of Pennsylvania PA. MD Research Thesis. Med Exam J \& Am J Med Sci Oct 1850.

6. Tomes J (1856) On the presence of the fibrils of soft tissues in the dentinal tubes. Phil Trans R Soc London. 146: 515-522.

7. Gysi A (1899) An attempt to explain the sensitiveness of dentin. Br J Dent Sci 43 865-868.

8. Brännström M (1963) A hydrodynamic mechanism in the transmission of painproduced stimuli through the dentin. In: Anderson DJ ed, Sensory Mechanisms in Dentine. New York, Pergamon Press. 73-79.

9. Kelley KW, Bergenholtz G, Cox CF (1981) The extent of the odontoblast process in rhesus monkeys (Macaca mulatta) as observed by scanning electron microscopy. Arch Oral Biol 26: 893-897. [Crossref]

10. Eifinger F (1969) The problem of pulp-dentin innervation. Dtsch Zahn Mund Kieferheilkd Zentralbl Gesamte 53: 188-201. [Crossref]

11. Gruerber H (1893) Myths of Greece and Rome. American Book Company, New York, Cincinnati, Chicago USA. 304-307.

12. Lambert S, Goodwin G (1929) Medical Leaders, Indianapolis IN. Bobbs-Merril Co.15-95.

13. Raschkow I (1835) Meletemata circa mammalium dentium evolutionem. Dissertatio inauguralis anatomico-physiologica. Friedlaender, Vratislaviae, Arch Anat Physiol University of Breslau. 385-390.

14. Cope Z (1961) Sir John Tomes, a pioneer of British dentistry. Dawson pubs. Pall Mall London1-26.

15. Cutler S (1866) Microscopy of the teeth. Dent Cosmos 8: pgs. 181, 308, 589.

16. Boll F (1868) Untersuchungen über die Zahnpulpa. Arch mikrosk Anat Entw Mech 4 73-86

17. Morgenstern M (1892) Über das Vorkommen von Nerven in der harten Zahnbeinsubstance. Deutsch Monatschr $f$ Zahnheilk 10: 436-437.

18. Morgenstern M (1896) Über Vorlaufige Mitteilung von Nerven in Dentine. Arch fmikr Anat 378-394.

19. Mummary J (1916) Innervation of the dentine. Dent Cosm 58: 258-269.

20. Toyoda (1927) Über die Innervationdes menschlichen Zahnbeins nebst der elektroosmotischen Auswaschungsmethode als neue. Nihon Shika Igakkai Kaishi (A Separate Volume).

21. Toyoda M (1934) Die Innervation des menschlichen Zahnbeins. Deut Zahnräzt Wochschr 37: 670-673.

22. Brashear A (1937) The controversy concerning the innervation of the teeth. $J$ Dent Res 16: 5-17.

23. Bradlaw R (1936) The innervation of the teeth. Proc Roy Soc Med 29:1040-1053.

24. Bernick S (1948) Innervation of the human tooth. Anat Rec 101: 81-107. [Crossref]

25. Fearnhead RW (1961) The neurohistology of human dentine. Proc R Soc Med 54: 877884. [Crossref]

26. Arwill T (1958) Innervation of the teeth: A study by light and electron microscopy. Trans Roy Sch Dent Stockholm \& Umea, Ivar Hæggströms Boktryckeri AB, Series 2:3.

27. Itoh K (1976) The distribution of nerves in human deciduous and permanent teeth. Arch Histol Jpn 39: 379-399. [Crossref]

28. Corpron RE, Avery JK (1973) The ultrastructure of intradental nerves in developing mouse molars. Anat Rec 175: 585-606. [Crossref]

29. Gunji T (1982) Morphological research on the sensitivity of dentin. Arch Histol Jpn 45: 45-67. [Crossref]

30. Gunji T, Gunji K, Hoshino M, et al. (1983) Morphological change of pulpal nerves with advancing years. Jpn J Oral Sci 25: 503-529.

31. Neill J (1842) Sensibility of the Teeth explained on Hydrostatic Principles. Graduate MD Thesis. University of Pennsylvania, Med Examiner J Vol: 3(2).

32. Neill J (1850) On the Manner in which External Impressions made upon the Teeth are conveyed to the Nervous Pulp within. Presented to the Philadelphia College of Physicians 24th April 1750 Am J Med Sci. Lea \& Blanchard Philadelphia Pa. pg. 558.

33. Gysi A, Rose C (1894) Sammlung von Mikrophotographen zur Vaeranschaulichung der mikroskopischen Strukur der Zahne der Menschen. (Gysi Zurich). 
Cox CF (2017) Sensory mechanisms in dentine: A literature review of light microscopy (LM), transmission microscopy (TEM), scanning microscopy (SEM) \& electro physiological (EP) tooth sensitivity: Is the ciliary organelle on the odontoblast the elusive primary nociceptor?

34. Brännström M, Astrom A (1964) A study on the mechanism of pain elicited from the dentine. J Dent Res 43: 613-625. [Crossref]

35. Brännström M, Johnson G (1978) The sensory mechanism in human dentin as revealed by evaporation and mechanical removal of dentin. J Dent Res 57: 49-53. [Crossref]

36. Tomes C (1876) A manual of dental anatomy: human and comparative. J \& A Churchill, London, England. 2nd ed.1-428.

37. Hopewell-Smith A (1893) Some observations on the cellular elements of the denta pulp. Trans odont Soc Lond 25-26.

38. Hopewell-Smith A (1893) The histology and pathohistology of the teeth and associated parts. Trans Odont Soc 171-172.

39. Hopewell-Smith A (1918) The normal and pathological histology of the mouth. Vol I. J \& A Churchill Publisher, London, England.

40. Tiegs OW (1932) Nerve endings in human teeth. J Anat 66: 622-627. [Crossref]

41. Avery JK, Rapp R (1958) Demonstration of cholinesterase in teeth. Stain Technol 33: 31-37. [Crossref]

42. Nachmansohn D (1948) The role of acetylcholine in conduction. Bull Johns Hopkins Hosp 83: 463-496. [Crossref]

43. Rapp R, Avery J, Strachan D (1964) Possible role of acetylcholinesterase in neural conduction within the dental pulp. In Biology of the Dental Pulp Organ: Symposium. SB Finn ed. Birmingham AL Press. Pg. 64.

44. Avery JK, Rapp R (1959) An investigation of the mechanism of neural impulse transmission in human teeth. Oral Surg Oral Med Oral Pathol 12: 190-198. [Crossref]

45. Brookhart JM, Livingston WK, Haugen FP (1953) Functional characteristics of afferent fibers from tooth pulp of cat. J Neurophysiol 16: 634-642. [Crossref]

46. Scott D, Tempel T (1963) Receptor potentials in response to thermal and other excitation. In: Sensory mechanisms in dentine: DJ Anderson ed. Pergamon Press, Oxford. 27-46.

47. Scott D, Gabel A, Shroff F (1953) Response pattern of sensory endings in tooth of the cat. Fed Proc 12: pgs. 129-130.

48. Horiuchi H, Matthews B (1974) Evidence on the origin of impulses recorded from dentine in the cat. $J$ Physiol 243: 797-829. [Crossref]

49. Yamada M (1963) Electrophysiological studies of excitation of dentine evoked by chemical means. In: Sensory mechanisms in dentine: DJ Anderson ed. Pergamon Press, Oxford. 47-59.

50. Adrian E (1963) Concluding Reactor remarks from Lord Adrian In: Sensory mechanisms in dentine: DJ Anderson ed. Pergamon Press, Oxford. Pg. 96.

51. Allard B, Magloire H, Couble M, et al. (2006) Voltage-gated sodium channels confer excitability to human odontoblasts: Possible role in tooth pain transmission. $J$ Biol Chem 281: 29002-29010.

52. Bartelstone HJ (1951) Radioiodine penetration through intact enamel with uptake by bloodstream and thyroid gland. J Dent Res 30: 728-733. [Crossref]

53. Gysi A (1900) An attempt to explain the sensitiveness of dentin. Br J Dent Sci 43: 865-868.

54. Orban B (1929) Oral Histology and embryology. 3rd edition, The P. Blakiston Son \& Co, Philadelphia. PA.

55. Orban B, Ritchie B (1945) Toothache under conditions simulating high altitude low atmosphereic pressure flight. J Am Dent Assoc 32: 145-180.

56. Harvey W (1947) Dental pain while flying or during decompression tests. Br Dent J 82: 113-118. [Crossref]

57. Rajpal P, Sachdev G, Waghmare M et al. (2014) Dental Barotrauma and Barodontilgia. J Med Sci Clin Res 2: 3477-3483.

58. Ozeki M (1975) The effects of eugenol on the nerve and muscle in crayfish. Comp Biochem Physiol C 50: 183-191. [Crossref]

59. Anderson W, McKinley R, Colavecchia M (1997) The use of clove oil as an anesthetic for rainbow trout and its effects on swimming performance. N Am J Fish Manag 17: 201-307.

60. Saydmohammed M, Pal A (2009) Anesthetic effect of eugenol and menthol on handling stress in Macrobrachium rosenbergii. Aquaculture 298: 162-167.

61. Cowing D, Powell A, Johnson M (2015) Evaluation of different concentration doses of eugenol on the behavior of Nephrops norvegicus. Aquaculture 442: 78-85.
62. Bernick S (1948) Innervation of the human tooth. Anat Rec 101: 81-107. [Crossref]

63. Bernick S (1957) Innervation of teeth and periodontium after enzymatic removal of collagenous elements. Oral Surg Oral Med Oral Pathol 10: 323-332. [Crossref]

64. Dobell C (1932) Antony van Leeuwenhoek and his little Animals. Harcourt, Brace and Co. New York. 428-438.

65. Zimmermann K (1898) Beitrage zur Kenntniss einiger Drusen und Epithelien. Archiv fur Mikroskopische Anatomie 52: 552-706.

66. Sorokin S (1962) Centrioles and the formation of rudimentary cilia by fibroblasts and smooth muscle cells. J Cell Biol 15: 363-377. [Crossref]

67. Garant PR, Szabo G, Nalbandian J (1968) The fine structure of the mouse odontoblast Arch Oral Biol 13: 857-876. [Crossref]

68. Eifinger F (1970) Die Mikromorphologic der menschlichen Zahnpulpa, Hanser, Munchen.

69. Turchi M, Kelley K, Cox C (1983) Contents of primate dentinal tubules: A comparative electron microscopic survey. J Dent Res 62: 283.

70. Cox C, Avery J, Corpron R (1974) Ultrastructural observations \& morphological Considerations of Ciliated Odontoblasts. J Dent Res 53: 402.

71. Abou Alaiwi WA, Lo ST, Nauli SM (2009) Primary cilia: highly sophisticated biological sensors. Sensors (Basel) 9: 7003-7020. [Crossref]

72. Bloodgood R (2009) From central to rudimentary to primary: the history of an underappreciated organelle whose time has come: The primary cilium. Meth Cell Biol 94: 3-52.

73. Bloodgood RA (2010) Sensory reception is an attribute of both primary cilia and motile cilia. J Cell Sci 123: 505-509. [Crossref]

74. Jennings H (1899) Studies on reactions to stimuli in unicellular organisims II. The mechanism of motor reactions to Paramecium. Am J Physiol 2: 311-341.

75. Haycraft CJ, Serra R (2008) Cilia involvement in patterning and maintenance of the skeleton. Curr Top Dev Biol 85: 303-332. [Crossref]

76. Whitfield JF (2008) The solitary (primary) cilium--a mechanosensory toggle switch in bone and cartilage cells. Cell Signal 20: 1019-1024. [Crossref]

77. Praetorius HA, Spring KR (2005) A physiological view of the primary cilium. Annu Rev Physiol 67: 515-529. [Crossref]

78. Nauli SM, Rossetti S, Kolb RJ, Alenghat FJ, Consugar MB, et al. (2006) Loss of polycystin-1 in human cyst-lining epithelia leads to ciliary dysfunction. $J \mathrm{Am} \mathrm{Soc}$ Nephrol 17: 1015-1025. [Crossref]

79. Nauli S, Alenghat F, Luo Y, et al. (2003) Polycystins 1 and 2 mediate mechanosensation in the primary cilium of kidney cells. Nat Genet 33: 129-137. [Crossref]

80. Xu C, Rossetti S, Jiang L, et al. (2007) Human ADPKD primary cyst epithelia cells with a novel, single codon deletion in the PKD1 gene exhibit defective ciliary polycystin localization and loss of flow-induced Ca2+ signaling. Am J Physiol Renal Physiol 292: 930-945. [Crossref]

81. Xu C, Shmukler B, Nishimura K, et al. (2009) Attenuated flow-induced ATP release contributes to absence of flow-sensitive, purinergic $\mathrm{Ca} 2+$ signaling in human ADPKD cyst epithelial cells. Am J Physiol Renal Physiol 296: 1464-1476. [Crossref]

82. Sorokin SP (1968) Reconstructions of centriole formation and ciliogenesis in mammalian lungs. J Cell Sci 3: 207-230. [Crossref]

83. Dutcher SK (1995) Flagellar assembly in two hundred and fifty easy-to-follow steps Trends Genet 11: 398-404. [Crossref]

84. Gherman A, Davis E, Katsanis N (2006) The ciliary proteome database: an integrated community resource for the genetic and functional dissection of cilia. Nat Genet 38: 961-962. [Crossref]

85. Fliegauf M, Benzing T, Omran H (2007) When cilia go bad: cilia defects and ciliopathies. Nat Rev Mol Cell Biol 8: 880-893. [Crossref]

86. Nauli S, Kawanabe Y, Kaminski J (2008) Endothelial cilia are fluid sensors that regulate calcium signaling and nitric oxide production through polycystine-1. Circulation 117: 1161-1171. [Crossref]

87. Abou Alaiwi W, Takahashi M, Mell B, et al. (2009) Ciliary polycystin-2 is mechanosensitive calcium channel involved in nitric oxide signaling cascades. Circ Res 104: 860-869. [Crossref]

88. Thivichon-Prince B, Couble ML, Giamarchi A, Delmas P, Franco B, et al. (2009) Primary cilia of odontoblasts: possible role in molar morphogenesis. $J$ Dent Res 88 910-915. [Crossref] 
Cox CF (2017) Sensory mechanisms in dentine: A literature review of light microscopy (LM), transmission microscopy (TEM), scanning microscopy (SEM) \& electro physiological (EP) tooth sensitivity: Is the ciliary organelle on the odontoblast the elusive primary nociceptor?

89. Höhling H (1966) Die Bauelemente von Zahnschmelz und Dentin aus morphologischer, chemischer und struktureller Sicht. Hanser, München.

90. Lester K, Boyde A (1968) The surface morphology of some crystalline components of dentine. In Symons, Dentine and pulp: A symposium. Univ. of Dundee Press. Dundee Scotland.

91. Spreter von Kreudenstein T (1958) Uber den Dentin liquor. Schweiz Med Wschr 88 635-649.

92. Paunio K, Näntö V (1965) Studies on the isolation and composition of interstitial fluid in swine dentine. Acta Odontol Scand 23: 411-421. [Crossref]

93. Cox C, Avery J (1975) Ultrastructural localization of autonomic endings adjacent to odontoblasts; A possible function. J Dent Res, 54: 1236. London, UK.

94. Avery J, Cox C (1977) Possible Role of Nerves in Teeth Relative to Pain \& Dentinogenesis. International Symposium: Physiological Sciences, The University of Bristol, Bristol, UK.

95. Inoue H, Kurosaka Y, Abe K (1992) Autonomic nerve endings in the odontoblast/ predentin border and predentin of the canine teeth of dogs. J Endod 18: 149-151. [Crossref]

96. Garant PR, Szabo G, Nalbandian J (1968) The fine structure of the mouse odontoblast. Arch Oral Biol 13: 857-876. [Crossref]

97. Garant PR (1972) The organization of microtubules within rat odontoblast processes revealed by perfusion fixation with glutaraldehyde. Arch Oral Biol 17: 1047-1058. [Crossref]

98. Holz J, Baume L (1973) Essais biologiques relatifs à la compatibilité des producits d'obturation intermediaire avec l'organe pulpo-dentinaire. Revue mens Odonto-stomat 83: $1369-1458$.

99. Schroeder H (1976) Orale Struckturbiologie, Entwicklungsgeschichte, Struktur und Funktion normaler Hart-und Weichgewebe der Mundhohle. Thieme Stuttgart.

100. Magloire H1, Couble ML, Romeas A, Bleicher F (2004) Odontoblast primary cilia: facts and hypotheses. Cell Biol Int 28: 93-99. [Crossref]
101. Hierck B, van der Heiden K, Alkemade F, et al. (2008) Primary cilia sensitize endothelial cells for fluid shear stress. Dev Dyn 237: 725-735.

102. Daubenmire RF (1936) The use of the terms coenocyte and syncytium in biology. Science 84: 533. [Crossref]

103. Chiba M, Nakagawa K, Mimura T (1967) DNA synthesis and cell division cycle at the base of the maxillary incisor tooth of the young rat. Arch Oral Biol 12: 865-876. [Crossref]

104. Watson ML, Avery JK (1954) The development of the hamster lower incisor as observed by electron microscopy. Am J Anat 95: 109-161. [Crossref]

105. Arwill T (1967) Studies on the ultrastructure of dental tissues. II. The predentinepulpal border zone. Odontol Revy 18: 191-208. [Crossref]

106. Frank RM (1968) Attachment sites between the odontoblast process and the intradentinal nerve fibre. Arch Oral Biol 13: 833-834. [Crossref]

107. Frank R (1968) Ultrastructural relationship between the odontoblast, its process and the nerve fibre. In Dentine \& Pulp: Their structure and Reactions. Ed. Symons N.B., Livingstone, London.115-145.

108. Takuma S (1960) Electron microscopy of the structure around the dentinal tubule. $J$ Dent Res 39: 973-981. [Crossref]

109. Takuma S, Nagai N (1971) Ultrastructure of rat odontoblasts in various stages of their development and maturation. Arch Oral Biol 16: 993-1011. [Crossref]

110. Holland GR (1975) Membrane junctions on cat odontoblasts. Arch Oral Biol 20 551-552. [Crossref]

111. Cox C, Avery J, Lee S, et al. (1976) Ultrastructual characterization of junctional complexes between odontoblasts. J Dent Res 55: 102.

112. Loewenstein WR (1966) Permeability of membrane junctions. Ann N Y Acad Sci 137: 441-472. [Crossref]

Copyright: (C2017 Cox CF. This is an open-access article distributed under the terms of the Creative Commons Attribution License, which permits unrestricted use, distribution, and reproduction in any medium, provided the original author and source are credited. 